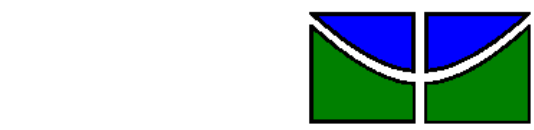

Universidade de Brasília

Faculdade de Economia, Administração e Contabilidade

Departamento de Administração

Curso de Graduação em Administração a distância

VALDIR VANIQUE DE SANTANA

\title{
QUALIDADE DE VIDA NO TRABALHO \\ NO AMBIENTE DAS AGÊNCIAS DO BANCO DO BRASIL DA REDE ENTORNO NORTE
}

Brasília - DF 


\section{VALDIR VANIQUE DE SANTANA}

\section{QUALIDADE DE VIDA NO TRABALHO NO AMBIENTE DAS AGÊNCIAS DO BANCO DO BRASIL DA REDE ENTORNO NORTE}

Monografia apresentada a Universidade de Brasília (UnB) como requisito parcial para obtenção do grau de Bacharel em Administração.

Professor Supervisor: Dr. Antonio Isidro

Professor Orientador: Profa. Maira Pinto Cauchioli Rodrigues

Brasília - DF 
Santana, Valdir Vanique

Qualidade de Vida no Trabalho no Ambiente das Agencias do Banco do Brasil da Rede Entorno Norte / Valdir Vanique de Santana. - Brasília, 2010.

77 f. : il.

Monografia (bacharelado) - Universidade de Brasília, Departamento de Administração - EaD, 2010.

Orientador: Prof. Maira Pinto Cauchioli Rodrigues, Departamento de Administração.

1. Qualidade de Vida no Trabalho - QVT. 2. Modelos de análise de QVT. 3. Banco do Brasil. 4. Trabalho de Conclusão de Curso. 5. Modelo de Walton. I. Título. 


\title{
VALDIR VANIQUE DE SANTANA
}

\section{QUALIDADE DE VIDA NO TRABALHO \\ NO AMBIENTE DAS AGÊNCIAS DO BANCO DO BRASIL DA REDE ENTORNO NORTE}

A Comissão Examinadora, abaixo identificada, aprova o Trabalho de Conclusão do Curso de Administração da Universidade de Brasília do aluno:

\section{Valdir Vanique de Santana}

\author{
Profa . Maira Pinto Cauchioli Rodrigues \\ Professor-Orientador
}

Prof. Dr. Antonio Isidro

Professor-Examinador
Profa . Késia Rozzett Oliveira

Professor-Examinador 
Dedico este trabalho à minha família, pelo incentivo e compreensão das ausências e a mim, como prêmio pela perseverança e realização de um sonho. 


\section{AGRADECIMENTOS}

Agradeço...

Primeiramente a Jeová Deus pelo dom da vida. À minha esposa Elenilde que muitas vezes me incentivou a não desistir. A meus filhos Alan e Natan que mesmo não compreendendo, aceitaram as minhas ausências. Aos meus colegas e amigos da turma J2 que contribuíram com a construção do meu conhecimento. Aos tutores do curso que ao longo desta caminhada me provocaram para superar meus limites e aos muitos anônimos que trabalharam nos bastidores para a realização do curso de graduação em administração à distância.

A todos, o meu muito obrigado! 
Viver com qualidade é, acima de tudo, aprender a desfrutar do que se tem, valorizar conquistas, empenhar-se no autoconhecimento, desenvolver posturas facilitadoras, cuidar da saúde física e emocional, ter lazer, desenvolver emocionalmente. Edina Bom Sucesso (1998) 


\section{RESUMO}

O presente trabalho teve como objetivo geral identificar a Qualidade de Vida no Trabalho - QVT sob a ótica dos bancários das agências da Rede Entorno Norte do Banco do Brasil e suas percepções em relação às ações de QVT realizadas por essa instituição. Para alcançar esses objetivos foram definidos como objetivos específicos a identificar as ações de QVT existentes no Banco do Brasil, buscar conhecer a opinião dos funcionários referentes às ações de QVT e também as sugestões que poderiam se implementadas para melhorar a qualidade de vida no trabalho na rede Entorno Norte. O referencial teórico básico estribou-se nas teorias de Walton (1973) e seu modelo de análise de QVT. Para o levantamento dos dados foi utilizado um questionário com questões voltadas para a identificação do perfil sócio-demográfico da população estudada; três questões abertas para investigar o conceito de QVT, a avaliação do programa de QVT do Banco do Brasil e as sugestões para melhorar a qualidade de vida no trabalho; e trinta e uma questões fechadas baseadas na teoria de Walton (1973), com escala de Ribeiro, em processo de validação. Os dados coletados foram analisados de forma qualitativa e quantitativa e as respostas dos participantes em conjunto com a escala utilizada indicaram que concordam razoavelmente que existe QVT no ambiente de trabalho das agências pesquisadas.

Palavras-chave: Qualidade de Vida no Trabalho - QVT. Modelos de Análise de QVT. Banco do Brasil. 


\section{LISTA DE TABELAS}

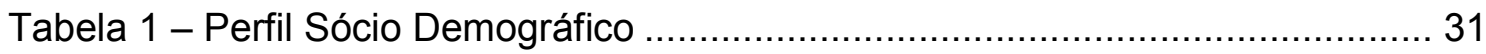

Tabela 2 - Relação entre Tempo de Banco e Faixa Etária ............................... 32

Tabela 3 - Relação entre Sexo e Status do Cargo ......................................... 32

Tabela 4 - Fator Suporte à Execução do Trabalho .................................... 38

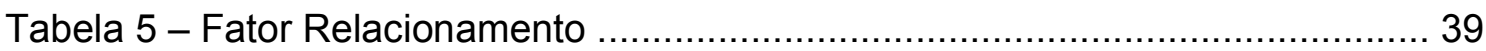

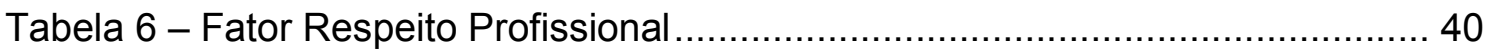

Tabela 7 - Fator Programas de Qualidade de Vida ........................................ 41

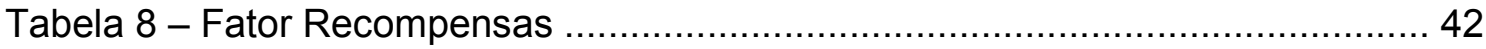

Tabela 9 - Opinião sobre o Programa de Qualidade de Vida do Banco do Brasil ... 46 


\section{SUMÁRIO}

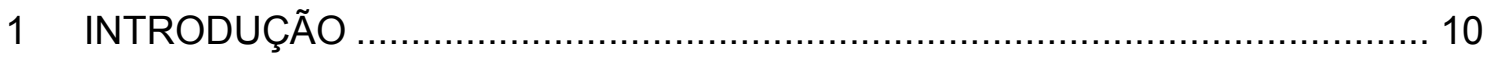

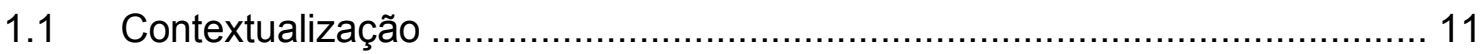

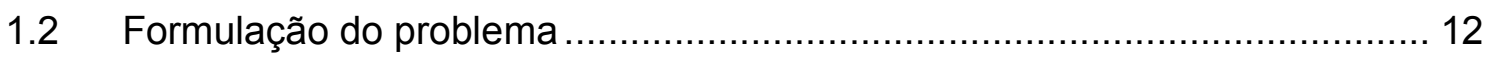

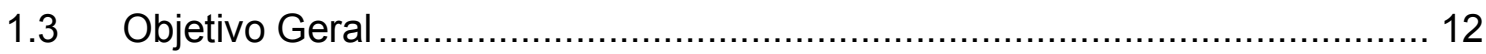

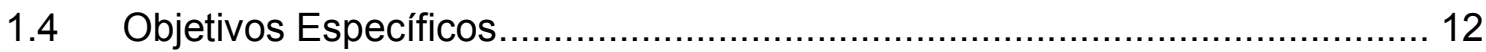

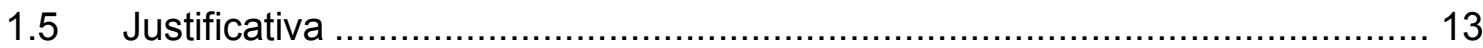

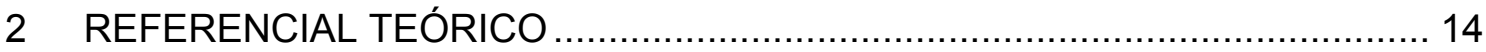

2.1 Evolução Histórica do Tema Qualidade de Vida no Travalho....................... 14

2.2 Definição de Qualidade de Vida no Trabalho............................................. 16

2.3 Modelos de Análise de Qualidade de Vida no Trabalho..............................19

2.3.1 Modelo de Walton (1973)................................................................19

2.3.2 Modelo de Hackman e Oldman (1975)..............................................22

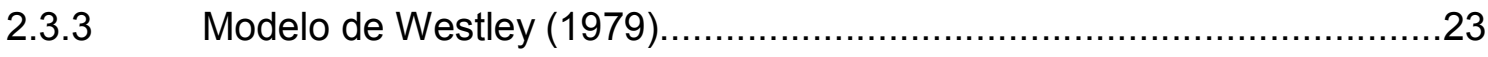

2.3.4 Modelo de Nadler e Lawer (1983) ...................................................24

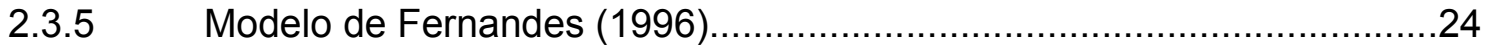

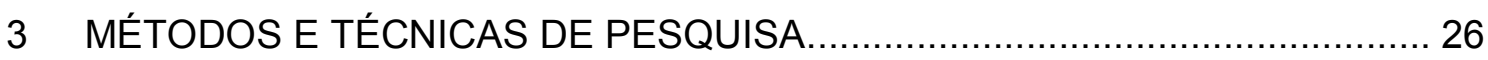

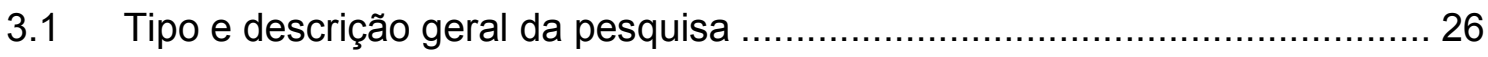

3.2 Caracterização da organização, setor ou área ............................................ 26

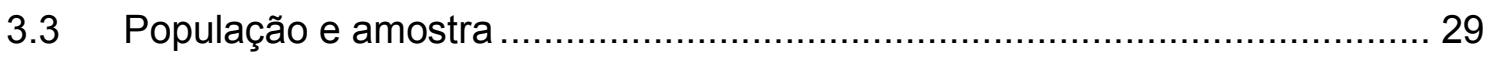

3.4 Caracterização dos instrumentos de pesquisa ........................................... 33

3.5 Procedimentos de coleta e de análise de dados......................................... 34

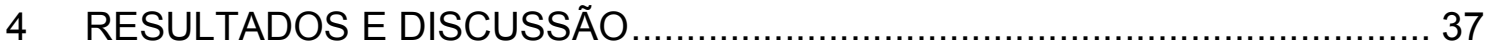

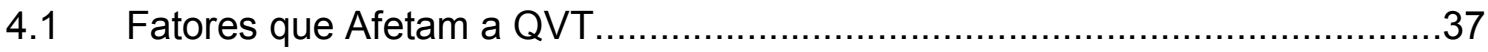

4.1.1 Suporte à Execução do Trabalho............................................................37

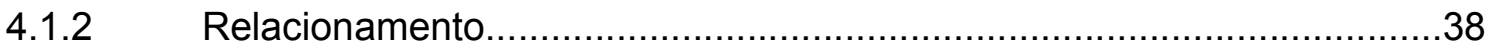




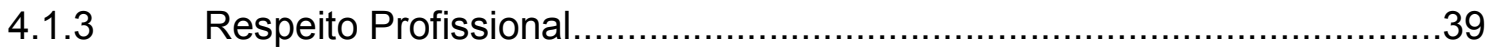

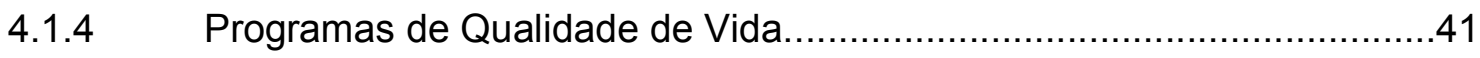

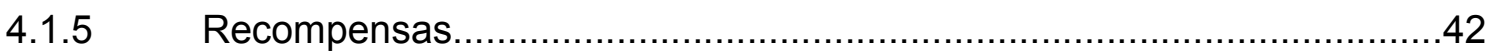

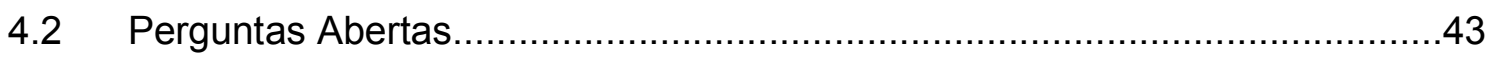

4.2.1 O que é Qualidade de Vida no Trabalho? .................................................

4.2.2 Opinião sobre o Programa de QVT do Banco do Brasil...........................45

4.2.3 Sugestões para contribuir com a Qualidade de Vida no Trabalho............47

5 CONCLUSÕES E RECOMEDAÇÕES ……………................................... 51

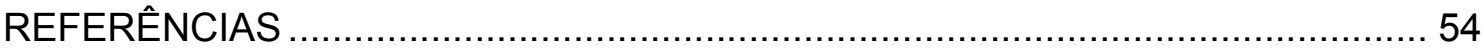

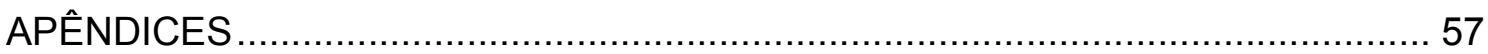

Apêndice A - Carta de Encaminhamento à Empresa............................................57

Apêndice B - Carta de Encaminhamento ao Participante ....................................... 58

Apêndice C - Instrumento de Coleta de Dados - Pares I e II....................................59

Apêndice D - Respostas à Pergunta: Para você, o que é QVT? ...............................60

Apêndice E - Respostas à Pergunta: Qual a sua opinião sobre o Programa

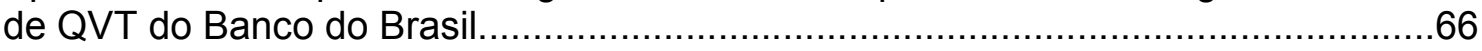

Apêndice $F$ - Respostas à Pergunta: Que Sugestões você faria para Contribuir com a Qualidade de Vida no seu Ambiente de Trabalho.......................................71

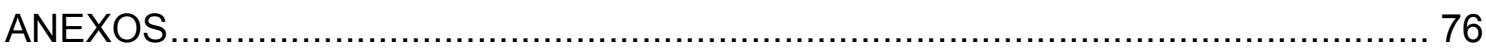

Anexo A - Instrumento de Coleta de Dados - Parte III ........................................ 76

Anexo B - Fatores de QVT - Teoria de Walton (Ribeiro, 2010) ............................ 77 


\section{INTRODUÇÃO}

O cenário de trabalho atual é altamente competitivo, exigindo a apresentação de resultados em tempo hábil, atingimento de metas e objetivos que oscilam a todo momento. Exigências como essas somadas à diminuição de custos, mão-de-obra escassa e aumento de produtividade faz com que o ser humano trabalhe no limite das suas forças.

De outro lado, a valorização do ser humano dentro das organizações ganhou destaque nas últimas duas décadas, sendo oferecidas várias formas de reconhecimento e remuneração, visando mantê-los produtivos e satisfeitos, embora ainda seja reduzido o número de empresas brasileiras que colocam em prática ações que visem a qualidade de vida no trabalho (QVT) de seu pessoal (TOLFO; PICCININI, 2001, p. 188).

Nesse cenário complexo encontram-se também inseridas as agências do Banco do Brasil, locais de trabalho de forte interação e representação humana, ambientes de muito atrito pessoal e alta carga de trabalho, onde o desgaste físico e mental é bastante acentuado. Onde seus funcionários, para que possam constituir uma vantagem competitiva no ambiente bancário, altamente competitivo, precisam perceber que são valorizados por meio de condições de trabalho adequadas e dignas, onde existam, e sejam percebidas, ações que propiciem QVT.

A temática Qualidade de Vida no Trabalho - QVT é de grande relevância, já que é na atividade laboral que os colaboradores passam um terço de seu dia e os melhores e mais produtivos anos de vida, os quais se vividos de forma digna resultarão na tão almejada felicidade, qualidade contagiante e motivadora (OLIVEIRA, 1998, p. 22). 


\subsection{Contextualização}

O Banco do Brasil foi o primeiro banco a operar no país e hoje é a maior instituição financeira do Brasil. Com mais de dois séculos de existência acumulou experiência e pioneirismo em muitas áreas, entre elas, a de gestão de pessoas.

A importância organizacional ${ }^{1}$ que o Banco do Brasil pretende dispensar aos seus funcionários encontra-se inserida tanto na sua missão quanto na visão de futuro.

\footnotetext{
Missão: Ser a solução em serviços e intermediação financeira, atender às expectativas de clientes e acionistas, fortalecer o compromisso entre os funcionários e a Empresa e contribuir para o desenvolvimento do País (Grifo nosso).

Visão de Futuro: Sermos o primeiro banco dos brasileiros no Brasil e no exterior, o melhor banco para trabalhar e referência em desempenho, negócios sustentáveis e responsabilidade socioambiental (Grifo nosso).
}

A preocupação em fortalecer o vínculo com os funcionários e em vislumbrar ser o melhor banco para se trabalhar encontram-se refletidos ainda em colocar a gestão de pessoas sobre a supervisão, não de uma Diretoria, Departamento ou Seção de Pessoal, e sim, entre uma das nove vice-presidências, mais precisamente a Vice-Presidência de Gestão de Pessoas e Desenvolvimento Sustentável, ligada diretamente ao presidente da instituição. Essa postura o coloca entre as instituições que adotam a Gestão Estratégica de Qualidade de Vida no Trabalho (GE-QVT), característica das empresas que inserem na missão, política da empresa e imagem corporativa sua ligação com a QVT (LIMONGI-FRANÇA, 2009, p. 256).

Para atingir os objetivos na gestão dos funcionários, mais especificamente no desenvolvimento da Qualidade de Vida no Trabalho, o Banco do Brasil promove ações e práticas de QVT dentro de suas unidades. Porém, ainda resta um longo caminho a percorrer já que no ano de 2009 a instituição não figurou entre as 150 melhores empresas para trabalhar, diferente de alguns concorrentes do conglomerado financeiro.

${ }^{1}$ Fonte:

http://www.bb.com.br/portalbb/page3,102,2640,0,0,1,6.bb?codigoMenu=616\&codigoNoticia=7605\&co digoRet $=5568 \&$ bread $=3$ 


\subsection{Formulação do problema}

Levando em conta a política estratégica do Banco do Brasil, sua experiência bicentenária no trato com pessoas e a situação atual quando comparada com as melhores empresas para trabalhar, de acordo com pesquisa da revista Exame, a proposta desta pesquisa foi responder a seguinte questão: qual a percepção dos funcionários em relação às ações de qualidade de vida no trabalho promovidas pelo Banco do Brasil, tomando como base a teoria de Walton (1973)?

Para a resolução da questão levantada tornou-se relevante conhecer o conceito de QVT mentalizado pelos funcionários do Banco do Brasil, as ações adotadas pela instituição para promover a qualidade de vida no trabalho, sugestões dos funcionários para contribuir com a melhoria da Qualidade de Vida no Trabalho e principalmente, caracterizar a QVT por meio de escala de avaliação da Qualidade de Vida no Trabalho dos participantes.

Pelo porte da instituição, com mais de cem mil funcionários, milhares de agência, diversas diretorias e centenas de órgãos internos, o campo de pesquisa ficou limitado às agências da Rede Entorno Norte do Distrito Federal, composta das agências Sobradinho, Serrana Sobradinho, Shopping Planaltina DF, Paranoá-DF, Planaltina GO e Formosa GO, ligadas à Superintendência Regional de Taguatinga, vinculada à Superintendência Estadual de Brasília.

\subsection{Objetivo Geral}

Identificar a percepção sobre a Qualidade de Vida no Trabalho sob a ótica dos bancários das agências da Rede Entorno Norte, em relação às ações de Qualidade de Vida no Trabalho - QVT, promovidas pelo Banco do Brasil.

\subsection{Objetivos Específicos}

Os objetivos específicos da pesquisa foram:

- Identificar as ações de QVT existentes; 
- Conhecer a opinião dos funcionários referente às ações de qualidade de vida no trabalho promovidas pelo Banco do Brasil;

- Identificar sugestões que possam ser implementadas para melhorar a qualidade de vida no trabalho na rede Entorno Norte do Banco do Brasil.

\subsection{Justificativa}

O Banco do Brasil possui políticas que indicam a sua clara intenção de melhorar a qualidade de vida dos seus funcionários. Esse fato é louvável tendo em vista o ambiente de trabalho constituir o local onde se passa grande parte da vida. Todavia, ainda há muito a fazer, já que no ambiente das agências é percebido a existência de atitudes desesperadas e estressantes, visando atingir metas organizacionais a qualquer custo em detrimento da saúde e do bem-estar do funcionário e pela incomoda situação de não ser percebido como o melhor banco para se trabalhar, conforme objetiva sua Visão de Futuro (ELGENNEN; CRUCIOL, 2009, p. 70).

Nesse sentido, o presente trabalho pesquisou sobre a qualidade de vida no trabalho dos funcionários do Banco do Brasil da Rede Entorno Norte do Distrito Federal a fim de identificar a percepção em relação às políticas de QVT adotadas pelo Banco do Brasil e relacionar sugestões de ações que podem ser implementadas para melhorar os programas já existentes e/ou a criação de novos de forma a contribuir para a melhoria da qualidade de vida no trabalho dos funcionários e a obtenção de resultados positivos para a empresa e, consequentemente para os clientes. 


\section{REFERENCIAL TEÓRICO}

\subsection{Evolução Histórica do tema Qualidade de Vida no Trabalho - QVT}

A preocupação com a QVT remonta desde o início da existência da humanidade. Evidência disso é que por volta de $1.515 \mathrm{AC}$, o escritor do livro bíblico de Êxodo, Moisés, ordenou à nação dos Israelitas que o trabalho deveria ser feito por seis dias e que no sétimo dia (um sábado) não deveriam fazer nenhuma sorte de obra laboriosa (Êxodo 20:8-11). Essa preocupação também consta dos ensinamentos de Euclides de Alexandria, 300 AC, que buscou a melhoria dos métodos de trabalho dos agricultores, à margem do rio Nilo, por meio da redução do esforço físico dos trabalhadores (RODRIGUES, 1994, p. 76).

$\mathrm{Na}$ era pós revolução industrial, quando os problemas relacionados ao trabalho agravam-se, foi a Escola de Relações Humanas que apresenta, na Teoria Administrativa, um ponto de identificação com a QVT, visto dar ênfase nos aspectos psicossociais e motivacionais do trabalhador. Todavia, é com o desdobramento dessa teoria, nas décadas de 50 e 60, paralelamente ao surgimento da Teoria Comportamental nas organizações, que a abordagem da Qualidade de Vida no Trabalho estabeleceu a sua verdadeira origem, com críticas à desumanização da sociedade, que desperta o interesse no aprofundamento dos estudos sobre a satisfação no ambiente de trabalho (MORAES et al, 1995, p. 177).

Entre os estudos iniciados na Década de 50, Eric Trist e seus colaboradores do Tavistok Institute, Londres, são apontados como os pioneiros das pesquisas ligadas à qualidade de vida no trabalho, com o início de uma série de estudos que deram origem a uma abordagem sociotécnica em relação à organização do trabalho, focados, sobretudo em uma preocupação com a satisfação e o bem-estar do trabalhador. No entanto, foi somente na década de 60 que o movimento tomou impulso, a partir da conscientização da importância de se buscar melhores formas de organizar o trabalho, com a finalidade de minimizar os seus efeitos negativos sobre o trabalhador e alcançar o seu bem-estar geral. Essa primeira fase da abordagem da QVT estendeu-se até 1974, quando em função da preocupação com 
questões econômicas, provocadas pela crise energética e crescente inflação, a necessidade de sobrevivência das empresas fez com que os interesses dos funcionários fossem relegados a segundo plano (TOLFO; PICCININI, 2001, p. 167).

A partir de 1979, com a perda de competitividade das indústrias norteamericanas, surge o fascínio pelas técnicas de administrar das concorrentes japonesas, marcando o início de uma nova fase de abordagem da QVT, e levando paises como Estados Unidos, França, Alemanha, Dinamarca Suécia, Noruega e Itália a estabelecerem métodos para uma maior satisfação pessoal no trabalho (HUSE \& CUMMINGS, 1985 apud RODRIGUES, 1994, p.78).

Nas últimas décadas a temática da qualidade de vida no trabalho vem ganhando considerável atenção. Todavia, ainda assim, existem incertezas conforme quadro de Definições Evolutivas da Qualidade de Vida no Trabalho apresentado por Nadler \& Lawler (1983, apud RODRIGUES, 1994, p.81):

\begin{tabular}{|l|l|l|}
\hline PERÍODO & $\begin{array}{l}\text { FOCO } \\
\text { PRINCIPAL }\end{array}$ & DEFINIÇÃO \\
\hline $1959 / 1972$ & Variável & $\begin{array}{l}\text { A QVT foi tratada como reação individual ao } \\
\text { trabalho ou às conseqüências pessoais de } \\
\text { experiência do trabalho. }\end{array}$ \\
\hline $1969 / 1975$ & Abordagem & $\begin{array}{l}\text { A QVT dava ênfase ao indivíduo antes da dar } \\
\text { ênfase aos resultados organizacionais, mas ao } \\
\text { mesmo tempo era vista como um elo dos projetos } \\
\text { cooperativos do trabalho gerencial. }\end{array}$ \\
\hline $1972 / 1975$ & Método & $\begin{array}{l}\text { A QVT foi o meio para o engrandecimento do } \\
\text { ambiente de trabalho e a execução de maior } \\
\text { produtividade e satisfação. }\end{array}$ \\
\hline $1975 / 1980$ & Movimento & $\begin{array}{l}\text { A QVT, como movimento, visa a utilização dos } \\
\text { termos "gerenciamento participativo" e "democracia } \\
\text { industrial" com bastante freqüência, invocado como } \\
\text { ideais do movimento. }\end{array}$ \\
\hline $1979 / 1980$ & Tudo & $\begin{array}{l}\text { A QVT é vista como um conceito global e como } \\
\text { uma forma de enfrentar os problemas de qualidade } \\
\text { e produtividade. }\end{array}$ \\
\hline
\end{tabular}




\begin{tabular}{|l|l|l|}
\hline Previsão & Nada & $\begin{array}{l}\text { A globalização da definição trará como } \\
\text { Futura }\end{array}$ \\
& & $\begin{array}{l}\text { conseqüência inevitável a descrença de alguns } \\
\text { setores sobre o tema QVT. E para estes QVT nada } \\
\text { representará. }\end{array}$ \\
\hline
\end{tabular}

Quadro 1: Definições evolutivas da Qualidade de Vida no Trabalho na visão de Nadler \& Lawler

Fonte: (NADLER; LAWLER, 1983, apud RODRIGUES, 1994, p.81).

No contexto moderno, a QVT procura oferecer ao trabalhador boas condições laborais para o desenvolvimento de sua tarefa com satisfação e bem-estar por meio do resgate dos valores humanos e ambientais, negligenciados em favor do avanço tecnológico, da produtividade e do crescimento econômico (TIMOSSI et al., 2009, p. 395).

\subsection{Definição de Qualidade de Vida no Trabalho}

Apesar da amplitude do termo, encontram-se, após breve revisão da literatura, as seguintes definições de Qualidade de Vida no Trabalho:

Para Walton (1973, apud TOLFO; PISCININI, 2001, P. 167):

A idéia de QVT é calcada em humanização do trabalho e responsabilidade social da empresa, envolvendo o entendimento de necessidades e aspirações do indivíduo, através da reestruturação do desenho de cargos e novas formas de organizar o trabalho, aliado a uma formação de equipes de trabalho com maior poder de autonomia e melhoria do meio organizacional.

A definição de Walton, um dos principais expoentes no estudo da qualidade de vida no trabalho salienta que a QVT não pode ser uma política de um departamento ou gerência, e sim de um todo, capaz de mexer com a própria estrutura da empresa. De acordo com Walton, o conceito de QVT enfatiza as necessidades e aspirações do ser humano, bem como a responsabilidade social do trabalhador. (TIMOSSI et al., 2009, p. 396).

Segundo Walton (1974, apud PEDROSO; PILATTI, 2009, p. 392), a qualidade de vida no trabalho é presente a partir do momento em que o colaborador atinge as suas metas, necessidades, aspirações e o senso de responsabilidade social.

Walton também relaciona QVT com os valores ligados ao coração das pessoas, fundamentado nos seus desejos e necessidades. Esse fato, segundo 
Garcia (2007, p. 14) explica o motivo de não haver um consenso exato quanto a definição de QVT visto que as "necessidades e os desejos humanos são elementos subjetivos e, por isso peculiares, que não podem ser padronizados, muito menos tratados com qualquer intenção de se obter exatidão".

Segundo Guest (1979 apud SIQUEIRA e COLETA, 1989, p.53):

QVT é um processo organizacional capaz de identificar o potencial criativo de seus empregados, envolvendo-os em processos decisórios que afetam suas vidas no trabalho [...] QVT é uma fase genérica que abrange os sentimentos pessoais sobre cada dimensão do trabalho.

A primeira conceituação concede à organização e seus dirigentes, o papel de verificar e executar as condições organizacionais para que o homem produza e sintase bem. A segunda visão compreende o papel do trabalhador mais pró-ativo: como um avaliador do sistema organizacional, acerca da satisfação de necessidades individuais dadas em função das condições de trabalho.

Para Nadler e Lawler (1983, p.26), QVT é:

[...] um modo de pensar sobre pessoas, trabalho e organizações. Seus elementos distintos são; 1) preocupação sobre o impacto do trabalho sobre as pessoas e a efetividade organizacional; 2) a idéia de participação na solução de problemas organizacionais e tomada de decisão.

Nadler e Lawer (1983) relacionam QVT ao poder participativo dos trabalhadores nas decisões da organização, à reestruturação do trabalho e de grupos autônomos de trabalho, às melhorias nas condições de trabalho e também a uma inovação no sistema de recompensas de forma a influenciar o clima organizacional.

Os conceitos de Nadler e Lawer salientam a necessidade de pesquisas e conhecimento de forma a contribuir para a compreensão do trabalho nas organizações, visando criar condições de integrar o homem no seu emprego, em um sentido amplo.

Para os autores Bowditch e Buono (1992, p. 207, apud TOLFO; PISCININI, 2001, P. 168):

[...] um conjunto de definições equaciona a QVT com a existência de um certo conjunto de condições e práticas organizacionais tais como cargos enriquecidos, participação dos empregados nos processos de tomada de decisões, condições seguras de trabalho e assim por diante. Uma outra abordagem equaciona a QVT com os efeitos visíveis que as condições de trabalho têm no bem-estar de um indivíduo (por exemplo, manifestação de satisfação no local de trabalho, crescimento e desenvolvimento dos funcionários, a capacidade de atender a toda a gama de necessidades humanas).

Esse conceito é importante em salientar que QVT não se concentra em debates teóricos e sim na prática de ações adotadas pelas organizações para a 
promoção da qualidade de vida no trabalho e satisfação dos empregados. QVT é percebido e influencia o modo de agir dos empregados.

A visão de associar QVT com práticas de qualidade de vida também é salientada por Bom Sucesso (1998, p. 45) que explicitou que:

viver com qualidade é, acima de tudo, aprender a desfrutar do que se tem, valorizar conquistas, empenhar-se no autoconhecimento, desenvolver posturas facilitadoras, cuidar da saúde física e emocional, ter lazer, desenvolver emocionalmente.

Para Fernandes (1996, p. 43), a QVT abrange a "conciliação dos interesses dos indivíduos e das organizações, ou seja, ao mesmo tempo em que melhora a satisfação do trabalhador, melhora a produtividade da empresa".

Segundo Albuquerque e Limongi-França (1998, p. 44), Qualidade de Vida no Trabalho é:

conjunto de ações de uma empresa que envolve diagnóstico e implantação de melhorias e inovações gerenciais, tecnológicas e estruturais dentro e fora do ambiente de trabalho, visando propiciar condições plenas de desenvolvimento humano para e durante a realização do trabalho.

Kátia de Carvalho Cunha, salienta ainda que:

QVT pode ser compreendida como resultado de políticas macro e microdimensionadas, intra e extra institucionais, que delineiam as práticas organizacionais, em interação e harmonia com características e necessidades pessoais e profissionais e com a natureza do processo e das relações de trabalho. (...) QVT evidencia-se como resultado de uma rede de variáveis interdependentes, que afetam o ambiente, a organização, o trabalhador, o processo e as relações de trabalho. (...) QVT pode decorrer de alguns benefícios organizacionais, mas não somente deles. A compreensão da QVT é um processo multifacetado e direcionado pela diversidade de referenciais e visões de mundo que sustentam os "olhares individuais" e coletivos (CUNHA, 2009, p.226-227).

Fica evidente que QVT volta-se para a conciliação dos interesses dos indivíduos e das organizações. Deve ser considerada como uma gestão dinâmica, porque empresas e pessoas mudam constantemente a visão de mundo. Deve-se ter em mente também que os aspectos físicos, sociológicos e psicológicos dos empregados precisam ser considerados já que afetam o ambiente em que trabalham. QVT não pode ser produzido de forma isolada, segundo Silva (2001, p. 10) é responsabilidade dos atores sociais do Estado, Empresa, Trabalhadores e Sindicato, através da preocupação conjunta e do compromisso com o ambiente e a sociedade em geral dentro de um contexto flexibilizado em decorrência das constantes mudanças. 


\subsection{Modelos de Análise de Qualidade de Vida no Trabalho}

\subsubsection{Modelo de Walton (1973)}

O modelo de qualidade de vida no trabalho criado por Richard Walton, nos Estados Unidos, em meio à crise petrolífera da década de 70 é o modelo de análise de QVT mais utilizado no Brasil visto ser considerado o mais completo, sendo utilizado, principalmente, por estudiosos da administração de recursos humanos e da psicologia organizacional. (PEDROSO; PILATTI, 2009 p. 41).

Walton (1973, apud FERNANDES, 1996, p.49-52) criou oito "critérios para a Qualidade de Vida no Trabalho" ou oito "categorias conceituais", modelo enumerado a seguir:

1) compensação adequada e justa: envolve as relações entre o pagamento $e$ fatores do trabalho, como treinamento, responsabilidade e condições de trabalho. Fatores como a oferta e procura do mercado, a média salarial de uma população e a participação nos lucros e resultados da empresa representam os indicadores que determinam o quão justo é o pagamento. (PEDROSO; PILATTI, 2009 p. 32) Essa categoria divide-se em três critérios:

a) remuneração adequada: aquela necessária para viver dignamente dentro das necessidades pessoais e dos padrões da sociedade em que vive;

b) equidade interna: igualdade na remuneração dentro da empresa;

c) equidade externa: igualdade na remuneração em relação a outros profissionais no mercado de trabalho.

2) condições de trabalho: aborda as condições físicas e a jornada de trabalho às quais o trabalhador é submetido em seu emprego. Envolve minimizar fatores que podem prejudicar a atuação do trabalhador, como odores, ruídos ou poluição visual. (PEDROSO; PILATTI, 2009 p. 33). Nesse critério integra-se os seguintes itens:

a) jornada de trabalho: relacionada ao número de horas trabalhadas e sua relação com as tarefas desempenhadas;

b) carga de trabalho: quantidade de trabalho em um turno;

c) ambiente físico: o local de trabalho, suas condições e organização;

d) material e equipamento disponiveis para o trabalho;

e) ambiente saudável: condições de segurança e de saúde do local de trabalho 
em relação ao risco de injúrias ou de doenças;

f) estresse a que é submetido na sua jornada de trabalho.

3) uso e desenvolvimento de Capacidades: visa mensurar as oportunidades que o empregado tem de aplicar seu saber e suas aptidões profissionais. $O$ autor estabelece cinco requisitos básicos para isso:

a) autonomia - diz respeito à liberdade que o trabalhador possui para executar seu trabalho;

b) significado da Tarefa - diz respeito à importância do trabalho realizado na vida e também ao trabalho de outras pessoas, internas e externas da organização;

c) identificação da Tarefa - refere-se à extensão da tarefa na sua integridade e avaliação dos resultados;

d) variedade da Habilidade - refere-se à possibilidade de receber informações acerca do desempenho do trabalho como um todo;

e) retroinformação - diz respeito à avaliar se o funcionário esta sendo informado sobre seu desempenho individual.

4) oportunidade de Crescimento e Segurança: tem relação com as oportunidades que a organização estabelece para o desenvolvimento e crescimento pessoal e com a segurança no emprego, quais sejam:

a) possibilidade de carreira: viabilidade de possibilitar avanços na organização, com reconhecimento pelos colegas, familiares e pela comunidade;

b) crescimento pessoal: educação continuada para desenvolver e aplicar as potencialidades individuais;

c) grau de segurança no emprego.

5) integração social na organização: engloba os aspectos vinculados ao relacionamento pessoal e auto-estima no local de trabalho, compreendido nos seguintes critérios:

a) igualdade de oportunidades: ausência de hierarquia em termos de "status" e ausência de preconceitos de cor, raça, sexo, religião e nacionalidade;

b) relacionamento: auxílio recíproco, apoio sócio-emocional, abertura interpessoal e respeito às individualidades; 
c) senso comunitário existente na instituição.

6) constitucionalismo: considera elementos chave para uma elevada Qualidade de Vida no Trabalho as normas que estabelecem os direitos e deveres dos trabalhadores, com destaque:

a) direitos Trabalhistas - envolve o cumprimento dos direitos dos trabalhadores assegurados em lei;

b) privacidade Pessoal - relativo ao grau de privacidade que os funcionários possuem dentro da organização;

c) liberdade de Expressão - liberdade para expressar suas opiniões de forma livre a seus superiores;

d) normas e Rotinas - diz respeito ao grau de influência das normas e rotinas da organização na execução das tarefas.

7) o trabalho e o espaço total de vida: necessidade de equilíbrio entre o trabalho e a vida pessoal do indivíduo, com a abrangência dos seguintes critérios:

a) papel balanceado no trabalho: equilíbrio entre exigências de carreira, jornada de trabalho e o convívio familiar;

b) horário de entrada e saída do trabalho: equilíbrio entre estes horários e o convívio familiar.

8) a relevância social da vida no trabalho: é a percepção do empregado em relação à responsabilidade social da empresa na comunidade, à qualidade de prestação dos serviços e atendimento aos funcionários, com destaque aos seguintes critérios:

a) imagem da organização: visão do empregado, orgulho e satisfação pessoais de pertencer a ela;

b) responsabilidade social da organização: percepção do empregado quanto à preocupação da organização em resolver os problemas da comunidade e também de não Ihe causar danos;

c) responsabilidade social pelos serviços: como o empregado percebe a responsabilidade da organização em relação à qualidade dos serviços colocados à disposição da comunidade;

d) responsabilidade social pelos empregados: visão do empregado em relação 
à política de recursos humanos da organização.

Essas oito dimensões formam um conjunto que possibilita ao pesquisador apreender os pontos percebidos pelos trabalhadores como positivos ou negativos na sua situação de trabalho, alem de apresentar a vantagem de analisar tanto o conjunto de condições e práticas organizacionais, como aspectos relacionados à satisfação e percepção dos empregados sobre os fatores positivos no trabalho (TOLFO; PISCININI, 2001, P. 169).

Com respeito às categorias de Walton, vale ressaltar que ele não desenvolveu uma avaliação e sim um modelo teórico que posteriormente foi balizado por outros autores, quantificado e transformado nos instrumentos de pesquisa presentes na literatura. Dentre os instrumentos mais utilizados no idioma português está o proposto por Fernandes (1996), que secciona os critérios de Walton em 35 sub-critérios (PEDROSO; PILATTI, 2009 p. 36).

\subsubsection{Modelo de Hackman e Oldham (1975)}

Hackman e Oldham (1975, apud NISHIMURA, 2008, p. 43-44) propõem um modelo de QVT que foi chamado de "Modelo das Dimensões Básicas da Tarefa", visto avaliar os aspectos das dimensões das tarefas, que proporcionam estados psicológicos críticos, vividos pelas pessoas em sua relação de trabalho, baseado nas seguintes características, com as definições de Chiavenato (2004, p. 392):

1) dimensões da tarefa: com seis atributos importantes para a satisfação no trabalho:

a) variedade de habilidades: grau em que a tarefa executada exige utilização de habilidades e talentos variados;

b) identidade da tarefa: o trabalho deve ser realizado do inicio até o fim para que haja percepção dos resultados;

c) significado da tarefa: concepção de como o seu trabalho produz conseqüências e impactos sobre o trabalho das outras pessoas;

d) inter-relacionamento: a tarefa deve possibilitar contato interpessoal do ocupante com outras pessoas ou com clientes internos e externos;

e) autonomia: grau de independência e liberdade que o trabalhador tem para programar seu trabalho e determinar os procedimentos para a execução; 
f) feedback (do próprio trabalho e extrínseco): grau em que o individuo recebe informações claras e diretas sobre o seu desempenho, tanto do próprio trabalho, quanto de subordinados, pares, superiores e clientes.

2) estados psicológicos críticos: envolvendo a percepção da significação do trabalho, da responsabilidade pelos resultados e o conhecimento pelos reais resultados do trabalho.

3) resultados pessoais e de trabalho: incluindo a satisfação geral e a motivação para o trabalho de alta qualidade, bem como o absenteísmo e a rotatividade baixa.

O modelo de Hackman e Oldham (1975) tem sido o segundo modelo mais utilizado no Brasil, perdendo apenas par ao modelo de Walton (LIMONGI-FRANÇA; 2006, p.4).

\subsubsection{Modelo de Westley (1979)}

Westley (1979, apud FERNANDES, 1996, p. 53) propõe um modelo para analisar a QVT baseado em quatro indicadores:

1) econômico: é representado pela eqüidade salarial e eqüidade no tratamento recebido, remuneração satisfatória, jornada de trabalho, ambiente externo, carga horária semanal e infra-estrutura do local de trabalho. Quando esse indicador encontra-se em desequilíbrio leva o trabalhador a sentir-se injustiçado;

2) político: é representado pela segurança no emprego, feedback, liberdade de expressão, relacionamento com a chefia, atuação sindical, participação nos lucros, interesse da Administração para com as unidades, comunicações internas, treinamentos oferecidos pela empresa. A conseqüência pelo desequilíbrio desse indicador é a insegurança;

3) sociológico: representado pela participação nas decisões, status, autonomia, relacionamento interpessoal, grau de responsabilidade. Está relacionado a uma falta de envolvimento moral, o que causa, conseqüentemente, a anomia;

4) psicológico: representado pela auto-realização, nível de desafio, desenvolvimento pessoal e profissional, criatividade, auto-avaliação, identidade da tarefa; demanda de trabalho. Sem estas características, o trabalhador cai no desinteresse para com o trabalho e para consigo. 


\subsubsection{Modelo de Nadler e Lawer (1983)}

O modelo de QVT de Nalder e Lawler (1983, apud RODRIGUES, 1994. p. 92), fundamenta-se em quatro aspectos:

1) participação dos funcionários nas decisões;

2) reestruturação do trabalho através do enriquecimento das tarefas e de grupos autônomos de trabalho;

3) inovação no sistema de recompensas para influenciar o clima organizacional e;

4) melhoria no ambiente de trabalho quanto às condições físicas e psicológicas, horário de trabalho, etc.

De acordo com Rodrigues (1994, p. 93) os principais fatores que levam ao sucesso dos projetos da qualidade de vida nas organizações, conforme o modelo de Nalder e Lawler são: percepção da necessidade; focar o problema e destacá-lo na organização; estruturar a identificação e solução do problema, teoria/modelo de projeto de treinamento de participantes; compensações projetadas tanto para os processos quanto para os resultados; envolvimento amplo da organização na realização do projeto.

Pelo modelo de Nadler e Lawler o indivíduo começa a fazer parte das organizações e apresenta uma evolução da importância das pessoas para a empresa, incluindo-os nas decisões e planejamento da organização.

\subsubsection{Modelo de Fernandes (1996)}

No Brasil, Fernandes (1996) é apontada pela literatura acadêmica como autora do modelo de auditoria de QVT denominado de Auditoria Operacional de Recursos Humanos para a Melhoria de Qualidade de Vida no Trabalho, baseado na literatura específica de QVT, em auditoria operacional e em conceitos de implementação de TQC (Total Quality Control), com o objetivo de utilizar o ciclo PDCA (Planejar, Desenvolver, Checar e Agir), seguindo o mesmo fluxo orientado para melhorias contínuas (NISHIMURA, 2008, p. 48).

De acordo com Nishimura (2008), o modelo de Eda C. Fernandes quando aplicado para melhorar a qualidade de vida no trabalho nas organizações, implica em: 
- Levantar o posicionamento do empregado em relação ao posto de trabalho ocupado, permitindo subsidiar a reestruturação do mesmo;

- Investigar os fatores do ambiente de trabalho que, se modificados, melhorariam a qualidade de vida dos empregados, definindo assim as causas influentes;

- Detectar os pontos críticos relativos às formas de organização do trabalho ou causas mais prováveis de insatisfação dos empregados;

- Especificamente, avaliar o nível de satisfação do empregado em relação às condições de trabalho, saúde, moral, compensação, participação, comunicação, imagem da empresa, relação chefia-subordinado e organização do trabalho;

- Elaborar um plano de ação com base em itens de controle que precisam ser melhorados;

- Após a implantação de medidas corretivas verificar, através do levantamento da percepção dos empregados, se as medidas corretivas diminuíram o nível de insatisfação evidenciado (NISHIMURA, 2008, p. 48). 


\section{MÉTODOS E TÉCNICAS DE PESQUISA}

\subsection{Tipo e descrição geral da pesquisa}

O presente estudo foi do tipo exploratório e descritivo, pois buscou descobrir e ao mesmo tempo descrever a relação entre as variáveis estudadas no universo dos funcionários da Rede Entorno Norte do Banco do Brasil quanto à temática Qualidade de Vida no Trabalho.

Quanto aos meios, ficou inserida no enquadramento de pesquisa de campo, com a aplicação de questionário baseado em evidências quantitativas e qualitativas, a fim de mensurar o grau de satisfação com a QVT, com perguntas abertas e fechadas, respondido individualmente, baseadas na teoria de QVT de Walton (1973) adaptado por Ribeiro (2010, p. 1-2).

Por pesquisa quantitativa entenda-se aquela cujo enfoque pode ser mensurado numericamente, que requer o uso de recursos e técnicas estatísticas. Já a pesquisa qualitativa parte do entendimento que existe uma relação dinâmica entre o mundo real e o sujeito e que a interpretação dos fenômenos e atribuição de significados são a básica do processo, não requerendo o uso de técnicas e métodos estatísticos, os dados são analisados indutivamente pelos pesquisadores (MATIASPEREIRA, 2006, p. 57). Por esses conceitos e abordagem utilizada na pesquisa, o tratamento dos dados ocorreu de forma mista.

\subsection{Caracterização da organização, setor ou área}

O Banco do Brasil ${ }^{2}$ foi fundado em 1808 por D.João. Tem mais de duzentos anos de existência, participou da história e cultura brasileira. É uma empresa de economia mista que além das atividades bancárias normais, atua nos ramos de seguridade, capitalização e previdência privada. 
Sua marca é uma das mais conhecidas e valiosas do País, relacionada à confiança, segurança, modernidade e credibilidade.

MISSÃO

Ser a solução em serviços e intermediação financeira, atender às expectativas de clientes e acionistas, fortalecer o compromisso entre os funcionários e a Empresa e contribuir para o desenvolvimento do País.

\section{VISÃO}

Ser o primeiro banco dos brasileiros no Brasil e no exterior, o melhor banco para trabalhar e referência em desempenho, negócios sustentáveis e responsabilidade socioambiental.

\section{VALORES}

- Ética e transparência.

- Compromisso com o desenvolvimento das comunidades e do País.

- Responsabilidade socioambiental.

- Excelência e especialização no relacionamento com o cliente.

- Gestão participativa, decisão colegiada e trabalho em equipe.

- Ascensão profissional baseada no mérito.

- Marca como diferencial competitivo.

- Conservadorismo e proatividade na gestão de riscos.

- Comprometimento com rentabilidade, eficiência e inovação.

Na questão dos valores, vale ressalta que Tamayo (1998, p. 2) afirma que a importância que uma organização dar a certos valores pode determinar a quantidade de esforços investidos na execução dos mesmos.

Nesse sentido e em sintonia com a missão, visão e valores defendidos na empresa, o Banco do Brasil, adota diversas ações no sentido de promover a Qualidade de Vida no Trabalho, entre as quais, podemos citar: remuneração baseada no mercado, programa de participação nos lucros e resultados, ponto eletrônico, programa de ascensão profissional, universidade corporativa, programa

\footnotetext{
${ }^{2}$ FONTE: www.bb.com.br, acessado em 22/05/2010
} 
de reconhecimento, ouvidoria interna, participação nos planos de saúde e previdência privada, linhas de crédito especiais para funcionários e programas sociais relevantes voltados para a comunidade, que repercutem positivamente no orgulho de se trabalhar na Empresa e de forma mais incisiva no tema abordado no trabalho o Programa QVT. ${ }^{3}$

O Programa QVT - Qualidade de Vida no Trabalho, lançado no mês de julho de 2007, em continuidade a um projeto Piloto implementado no decorrer de 2004, tem como objetivo promover qualidade de vida no trabalho dos funcionários e colaboradores, com foco no estímulo aos cuidados com a saúde e na adoção de hábitos saudáveis e está ancorado em ações de Comunicação Interna, Educação, Experimentação e Suporte, dentro as quais se destacam as seguintes ações:

a. Programa de Educação em Saúde e Segurança do Trabalhador no BB Conjunto de ações de capacitação que visam promover a adoção de hábitos saudáveis e a observação dos cuidados com a própria saúde;

b. Página de Qualidade de Vida no Trabalho - Página disponível na Intranet, veiculando conteúdos voltados para saúde, segurança e qualidade de vida no trabalho;

c. Grupos de Discussão na Intranet - Ambiente disponível na Intranet, aberto aos funcionários, para comentários sobre temas relacionados à qualidade de vida no trabalho;

d. Campanhas de saúde e segurança do trabalho - Campanhas periódicas, utilizando os veículos de comunicação interna do Banco, visando à prevenção de doenças (diabetes, hipercolesterolemia, hipertensão, câncer, obesidade, dependência química, entre outras) e acidentes de trabalho;

e. Serviço de Consultoria - direcionada a funcionários e colaboradores sobre assuntos relacionados à saúde, segurança e qualidade de vida no trabalho, utilizando-se da formação de equipe multidisciplinar, além do apoio a eventos locais;

f. Verba QVT - Valor destinado a cada dependência do Banco para a realização de práticas que visem a promoção e a proteção da saúde (Ex. ginástica laboral, relaxamento, alongamento, ioga no trabalho, tai chi chuan, liang gong e massagem expressa);

${ }^{3}$ (http://intranet.bb.com.br/portal/APPS/vida/bnfc/qvt/index.jsp, acessado em 01/06/2010). 
g. Semana de Qualidade de Vida no Trabalho - Durante a semana do Dia Mundial da Saúde (07 de abril), são realizados diversos eventos, dentre eles, as Feiras regionais de QVT;

h. Espaços de Qualidade de Vida - áreas para a prática de atividade antiestresse, coletivas ou individuais, relaxamento e descanso dos funcionários, adolescentes trabalhadores e estagiários;

i. Programa Agita - baseado nas premissas na ONG Agita Mundo (Move for Health NGO) e que tem os seguintes objetivos: estimular a atividade física e a saúde, mediante a promoção de eventos para a comunidade; disseminar amplamente os benefícios sociais e individuais de 30 minutos diários de atividade física moderada; compartilhar boas práticas em websites, workshops e publicações e promover e disseminar informação sobre abordagens inovadoras para desenvolver alianças no mundo visando a promoção da atividade física e saúde;

j. Convênios QVT - parcerias entre o Banco do Brasil e empresas externas ligadas às áreas de promoção da saúde e qualidade de vida, com o objetivo de proporcionar aos funcionários, estagiários e adolescentes trabalhadores, condições especiais de acesso a bens e serviços que promovam a saúde e qualidade de vida;

k. Equipe de Comunicação e Autodesenvolvimento - ECOA - equipe formada por voluntários de diversos setores e níveis hierárquicos que tem por objetivo auxiliar os comitês da administração nas ações de responsabilidade socioambiental/ecoeficiência, voluntariado empresarial, comunicação interna, clima organizacional, reconhecimento, capacitação e qualidade de vida dos funcionários.

\subsection{População e amostra ou participantes do estudo}

Em um universo de mais de cem mil funcionários, lotados em Diretorias, Superintendências, Estaduais, Regionais, Agências e unidades de Suporte Operacional e também por uma questão de características semelhantes, a pesquisa de campo foi realizada na Rede Entorno Norte do Distrito Federal, vinculada à 
Gerência de Varejo de Taguatinga (Superintendência Regional de Taguatinga), pertencente à Superintendência Estadual do Distrito Federal.

A Gerência de Varejo de Taguatinga é composta de quarenta e cinco agências, divididas em sete redes de agências - Taguatinga, Entorno Norte, Entorno Sul, Industrial, Satélite Sul, Nordeste de Goiás e Entorno Oeste.

A Rede Entorno Norte é integrada por seis agências, possuem em comum a proximidade, tratarem-se de agência de "calçada", geralmente apenas uma agência na cidade (exceção de Sobradinho) e com foco no Agronegócio.

$\mathrm{Na}$ aplicação dos questionários buscou-se atingir a população total da Rede de Entorno Norte, porém, nos dias em que foi aplicado o Instrumento de coleta de dados (APÊNDIECE C e ANEXO A) por motivos diversos, tais como férias, licença saúde, vacância, falta ao trabalho, abono assiduidade, falta de interesse do funcionário em participar da pesquisa, os participantes efetivos ficaram limitados a 92 funcionários, o que representa $63 \%$ da possibilidade total da população pesquisada, distribuídos entre as agências da seguinte forma, conforme tabela 1:

- $24(26,1 \%)$ da agência Formosa GO, prefixo 0377;

- 26 (28,3\%) da agência Sobradinho, prefixo 1226;

- 7 ( 7,6\%) da agência Paranoá , prefixo 1423;

- 12 (13,0\%) da agência Planaltina GO, prefixo 2462;

- $18(19,6) \%)$ da agência Shopping Planaltina DF, prefixo 3264; e

- 5 ( 5,4\%) da agência Serrana-Sobradinho, prefixo 4313.

A distribuição por gênero foi de $25 \%(n=23)$ do sexo Feminino e $75 \%(n=69)$ do sexo Masculino. A faixa etária que apresentou o maior percentual de participantes $(42,4 \%, n=39)$ foi de 26 a 35 anos e o menor percentual entre a idade 18 a 25 anos (13,0\%, n= 12). Quanto ao estado civil, 29,3\% ( $n=27)$ dos indivíduos são Solteiros, viúvos ou separados e $70,7 \%(n=65)$, grande maioria, são casados ou vivem em união estável.

Em relação à escolaridade, os funcionários da Rede Entorno Norte, possuem formação superior visto que a grande maioria, 46,7\% $(n=43)$ possui curso de graduação completa, 26,1\% ( $n=24)$ estão com o curso de graduação incompleto, $19,6 \%$ ( $n=18$ ) possui curso de Pós-Graduação, Mestrado ou Doutorado e apenas uma pequena parte dos funcionários, 7,6\% $(n=7)$ possuem apenas o ensino médio. A agência que possui o maior número de funcionários apenas com o ensino médio é a agência de Sobradinho, prefixo 1226, com 11,5\% $(n=3)$ e a agência de Formosa 
GO, prefixo 0377 possui $33,3 \%$ dos seus funcionários com Pós, Mestrado o Doutorado.

Tabela 1 - Perfil Sócio-Demográfico

\begin{tabular}{|c|c|c|c|c|c|c|c|c|c|c|c|c|c|c|}
\hline \multirow[b]{2}{*}{ Sexo } & \multicolumn{7}{|c|}{ Freqüência } & \multicolumn{7}{|c|}{ Percentual } \\
\hline & 377 & 1226 & 1423 & 2462 & 3264 & 4313 & Geral & 377 & 1226 & 1423 & 2462 & 3264 & 4313 & Geral \\
\hline Feminino & 8 & 7 & 1 & 2 & 2 & 3 & 23 & 33,3 & 26,9 & 14,3 & 16,7 & 11,1 & 60,0 & 25,0 \\
\hline Masculino & 16 & 19 & 6 & 10 & 16 & 2 & 69 & 66,7 & 73,1 & 85,7 & 83,3 & 88,9 & 40,0 & 75,0 \\
\hline Total & 24 & 26 & 7 & 12 & 18 & 5 & 92 & 100,0 & 100,0 & 100,0 & 100,0 & 100,0 & 100,0 & 100,0 \\
\hline Faixa Etária & 377 & 1226 & 1423 & 2462 & 3264 & 4313 & Geral & 377 & 1226 & 1423 & 2462 & 3264 & 4313 & Geral \\
\hline 18 a 25 anos & 3 & 1 & 1 & 2 & 5 & 0 & 12 & 12,5 & 3,8 & 14,3 & 16,7 & 27,8 & 0,0 & 13,0 \\
\hline 26 a 35 anos & 11 & 12 & 4 & 4 & 4 & 4 & 39 & 45,8 & 46,2 & 57,1 & 33,3 & 22,2 & 80,0 & 42,4 \\
\hline 36 a 45 anos & 6 & 5 & 1 & 1 & 8 & 1 & 22 & 25,0 & 19,2 & 14,3 & 8,3 & 44,4 & 20,0 & 23,9 \\
\hline Acima de 46 anos & 4 & 8 & 1 & 5 & 1 & 0 & 19 & 16,7 & 30,8 & 14,3 & 41,7 & 5,6 & 0,0 & 20,7 \\
\hline Total & 24 & 26 & 7 & 12 & 18 & 5 & 92 & 100,0 & 100,0 & 100,0 & 100,0 & 100,0 & 100,0 & 100,0 \\
\hline Estado Civil & 377 & 1226 & 1423 & 2462 & 3264 & 4313 & Geral & 377 & 1226 & 1423 & 2462 & 3264 & 4313 & Geral \\
\hline Solt/Viúv/Div/Sepa & 6 & 6 & 5 & 1 & 5 & 4 & 27 & 25,0 & 23,1 & 71,4 & 8,3 & 27,8 & 80,0 & 29,3 \\
\hline Casado/União Estl & 18 & 20 & 2 & 11 & 13 & 1 & 65 & 75,0 & 76,9 & 28,6 & 91,7 & 72,2 & 20,0 & 70,7 \\
\hline Total & 24 & 26 & 7 & 12 & 18 & 5 & 92 & 100,0 & 100,0 & 100,0 & 100,0 & 100,0 & 100,0 & 100,0 \\
\hline Escolaridade & 377 & 1226 & 1423 & 2462 & 3264 & 4313 & Geral & 377 & 1226 & 1423 & 2462 & 3264 & 4313 & Geral \\
\hline Ensino Médio & 1 & 3 & 1 & 1 & 1 & 0 & 7 & 4,2 & 11,5 & 14,3 & 8,3 & 5,6 & 0,0 & 7,6 \\
\hline Graduação Incomp & 4 & 7 & 0 & 3 & 7 & 3 & 24 & 16,7 & 26,9 & 0,0 & 25,0 & 38,9 & 60,0 & 26,1 \\
\hline Graduação Compl & 11 & 11 & 4 & 6 & 9 & 2 & 43 & 45,8 & 42,3 & 57,1 & 50,0 & 50,0 & 40,0 & 46,7 \\
\hline Pós/Mestrado/Dout & 8 & 5 & 2 & 2 & 1 & 0 & 18 & 33,3 & 19,2 & 28,6 & 16,7 & 5,6 & 0,0 & 19,6 \\
\hline Total & 24 & 26 & 7 & 12 & 18 & 5 & 92 & 100,0 & 100,0 & 100,0 & 100,0 & 100,0 & 100,0 & 100,0 \\
\hline Tempo Serviço & 377 & 1226 & 1423 & 2462 & 3264 & 4313 & Geral & 377 & 1226 & 1423 & 2462 & 3264 & 4313 & Geral \\
\hline 0 a 5 anos & 13 & 11 & 6 & 9 & 10 & 5 & 54 & 54,2 & 42,3 & 85,7 & 75,0 & 55,6 & 100,0 & 58,7 \\
\hline 6 a 10 anos & 6 & 5 & 1 & 0 & 5 & 0 & 17 & 25,0 & 19,2 & 14,3 & 0,0 & 27,8 & 0,0 & 18,5 \\
\hline 11 a 20 anos & 2 & 1 & 0 & 1 & 0 & 0 & 4 & 8,3 & 3,8 & 0,0 & 8,3 & 0,0 & 0,0 & 4,3 \\
\hline Acima de 21 anos & 3 & 9 & 0 & 2 & 3 & 0 & 17 & 12,5 & 34,6 & 0,0 & 16,7 & 16,7 & 0,0 & 18,5 \\
\hline Total & 24 & 26 & 7 & 12 & 18 & 5 & 92 & 100,0 & 100,0 & 100,0 & 100,0 & 100,0 & 100,0 & 100,0 \\
\hline Status da Função & 377 & 1226 & 1423 & 2462 & 3264 & 4313 & Geral & 377 & 1226 & 1423 & 2462 & 3264 & 4313 & Geral \\
\hline Chefia & 5 & 6 & 2 & 4 & 6 & 1 & 24 & 20,8 & 23,1 & 28,6 & 33,3 & 33,3 & 20,0 & 26,1 \\
\hline Subordinado & 19 & 20 & 5 & 8 & 12 & 4 & 68 & 79,2 & 76,9 & 71,4 & 66,7 & 66,7 & 80,0 & 73,9 \\
\hline Total & 24 & 26 & 7 & 12 & 18 & 5 & 92 & 100,0 & 100,0 & 100,0 & 100,0 & 100,0 & 100,0 & 100,0 \\
\hline
\end{tabular}

Fonte: Pesquisa de Campo

Quanto ao tempo de Serviço, a grande maioria, 58,7\% $(n=54)$ possui entre 1 mês e 5 anos, 18,5\% (n=17) esta na faixa de 6 a 10 anos, 4,3\% (n= 4) possui entre 11 e 20 anos e 18,5\% (n=17) esta na faixa acima de 21 anos de tempo de serviço no Banco do Brasil. A agencia Serrana-Sobradinho, prefixo 4313 possui o maior percentual de funcionários com menor tempo de serviço (100\%) e a agência 
Sobradinho, prefixo 1226, possui o maior número de funcionários na faixa acima de 21 anos $34,6 \%(n=9)$.

Embora o tempo de serviço na Rede Entorno Norte seja baixo, nota-se com a comparação entre as faixas etárias (Tabela 2) que a grande maioria dos funcionários com tempo de serviço até 5 anos, não são jovens no início de carreira já que 59,2\% $(n=32)$ possuem entre 26 e 35 anos.

Tabela 2 - Relação entre Tempo de Banco e Faixa Etária

\begin{tabular}{|c|c|c|c|c|c|}
\hline \multirow[b]{2}{*}{ Tempo de Banco } & \multicolumn{4}{|c|}{ Idade } & \multirow[b]{2}{*}{ Total } \\
\hline & 18 a 25 anos & 26 a 35 anos & 36 a 45 anos & $\begin{array}{c}\text { Acima de } 46 \\
\text { anos }\end{array}$ & \\
\hline 0 a 5 anos & 11 & 32 & 7 & 4 & 54 \\
\hline 6 a 10 anos & 1 & 5 & 9 & 2 & 17 \\
\hline 11 a 20 anos & 0 & 1 & 1 & 2 & 4 \\
\hline Acima de 21 anos & 0 & 1 & 5 & 11 & 17 \\
\hline Total & 12 & 39 & 22 & 19 & 92 \\
\hline
\end{tabular}

Fonte: Pesquisa de Campo

Ainda no perfil sócio demográfico dos funcionários da Rede Entorno Norte $26,1 \%$ ( $n=24)$ responderam que ocupam cargo de chefia e $73,9 \%$ ( $n=68)$ estão em uma posição de subordinado. A relação dos ocupantes de cargo de chefia com o gênero e bastante discrepante já que apenas $8,3 \%(n=2)$ das mulheres ocupam cargo em comissão (Tabela 2).

Tabela 3 - Relação entre Sexo e Status do Cargo

\begin{tabular}{|l|r|r||r|}
\hline \multirow{2}{*}{ Sexo } & \multicolumn{2}{|c|}{ Status do Cargo } & \multirow{2}{*}{ Total } \\
\cline { 2 - 3 } & \multicolumn{1}{|c|}{ Chefia } & Subordinado & \multicolumn{1}{|c|}{ Tot } \\
\hline Feminino & 2 & 21 & 23 \\
\hline Masculino & 22 & 47 & 69 \\
\hline Total & 24 & 68 & 92 \\
\hline Fonte: Pesquisa de Campo
\end{tabular}

Estes dados estão de acordo com a afirmação de Faria e Rachid (2007, p. 86) de que as mulheres encontram-se mais inseridas em postos de níveis hierárquicos inferiores, em trabalhos de horas reduzidas, predominantemente funções de menores salários. 


\subsection{Caracterização do instrumento de pesquisa}

Para Matias-Pereira (2006, p. 58) a definição do instrumento de coleta de dados dependerá dos objetivos que se pretende alcançar e do universo a ser investigado. Por esse pressuposto foi adotado nesta pesquisa o instrumento na forma de questionário, definido como uma série ordenada de perguntas, que podem ser abertas ou fechadas (MATIAS-PEREIA, 2006, p. 58).

O instrumento utilizado, constante do Apêndice $C$ e Anexo $A$, é composto por três partes, com perguntas abertas e fechadas, que foram respondidas individualmente e sem identificação.

$\mathrm{Na}$ primeira parte do instrumento houve a caracterização do perfil dos participantes do estudo, contemplando informações do tipo: agência pertencente, faixa etária, sexo, estado civil e escolaridade.

A segunda parte é composta de três questões subjetivas que tiveram como objetivo descobrir o conceito mentalizado de QVT por parte dos participantes, opinião e percepção sobre o programa de QVT do Banco do Brasil e sugestões que foram analisadas e citadas, de acordo com a relevância por ocasião da análise dos dados coletados.

A terceira parte é constituída de trinta e uma questões fechadas, baseadas na teoria de Walton (1999), que se encontra em processo de validação estatística por Ribeiro (2010, p. 1-2), que foram respondidas utilizando-se uma escala intervalar, contínua de cinco pontos, assim descritos: 0 = Discordo; 1 = Concordo Pouco; 2 = Concordo Razoavelmente; 3 = Concordo Muito; 4 = Concordo Totalmente. Constou ainda da terceira parte duas questões referente a tempo de serviço na organização e status do cargo atual (chefia ou subordinado).

Os itens da terceira parte do Instrumento de pesquisa foram submetidos a uma validação semântica por Ribeiro (2010, p. 1-2) e, posteriormente, com os resultados da aplicação, foram identificados cinco fatores decorrentes da análise de conteúdo dos itens, realizada por sete juízes. São eles: 1) Suporte à Execução do Trabalho; 2) Relacionamento; 3) Respeito Profissional; 4) Programas de Qualidade de Vida; e 5) Recompensas (ANEXO B).

Em Suporte à Execução do Trabalho estão inseridos os seguintes itens: 1 (Valoriza o trabalho dos funcionários); 3 (Dá liberdade para o funcionário executar o 
trabalho com seu estilo pessoal); 4 (Fornece a infra-estrutura material necessária para a execução do trabalho); 7 (Fornece um bom suporte tecnológico para o desempenho do trabalho); 12 (Investe para que o ambiente físico de trabalho seja saudável); 13 (Assegura uma adequada jornada de trabalho); 21 (Oferece treinamento para os funcionários); e 23 (Tem um sistema de comunicação claro).

O fator Relacionamento engloba os itens: 8 (Possibilita relações sociais agradáveis entre os funcionários); 9 (Estimula o bom relacionamento entre chefias e funcionários); 16 (Exige respeito dos superiores para com seus colaboradores); 17 (Estimula o apoio dos superiores a seus colaboradores); e 18 (Exige respeito dos colaboradores para com seus superiores).

No fator Respeito Profissional são contemplados os itens: 5 (Apóia o desenvolvimento pessoal); 6 (Investe para que o funcionário não mude de empresa); 11 (Faz os funcionários se sentirem orgulhosos por trabalhar nela); 25 (Respeita os direitos trabalhistas); 26 (Respeita a liberdade de expressão); 27 (Respeita a privacidade); 29 (Possibilita a realização profissional dos seus funcionários); e 30 (Investe na segurança dos funcionários).

Inseridos no fator Programas de Qualidade de Vida estão os itens: 14 (Oferece assistência médica); 15 (Oferece assistência odontológica); 20 (Oferece bolsas de estudo para os funcionários); 28 (Promove eventos de recreação e lazer); e 31 (Desenvolve programas de qualidade de vida no trabalho).

E, por sua vez, o fator Recompensas envolve os itens seguintes: 2 (Recompensa a competência no trabalho); 10 (Paga salários justos); 22 (Tem um sistema de promoção justo); 19 (Reconhece os bons funcionários); e 24 (Reconhece os funcionários leais).

\subsection{Procedimentos de coleta e de análise de dados}

Inicialmente foi encaminhada às agências envolvidas a carta constate do Apêndice A, por meio do malote do Banco do Brasil e posteriormente mantido contato telefônico para agendar visita a fim de aplicar o Instrumento de Coleta de Dados (Apêndice C e Anexo A). 
No dia agendado, o pesquisador entregou a cada participante um conjunto composto de uma carta ao participante explicando os objetivos da pesquisa (Apêndice B) e um Instrumento de Coleta de Dados. Também informou ao participante que não deveria colocar o nome e foi pedido que, se possível, fosse preenchido todas as questões. Os dados coletados foram tabulados em uma planilha do aplicativo Excel com quarenta e duas colunas.

Após a tabulação dos dados coletados foi realizada a aglutinação dos itens das colunas correspondentes às questões fechadas (itens 1 a 31) nos 5 fatores identificados por Ribeiro (2010) (1- Suporte à Execução do Trabalho; 2Relacionamento; 3- Respeito Profissional; 4- Programas de Qualidade de Vida; e 5Recompensas), conforme divisão constante da descrição do instrumento, sendo submetidos à análise estatística descritiva, com cálculo de médias e desvio padrão, por meio da utilização dos aplicativos Excel e SPSS 17.0.

Os resultados obtidos com a análise dos dados foram apresentados por meio da construção tabelas e gráficos.

A parte III do instrumento teve uma análise qualitativa, que segundo Roesch (2005, p. 169) é o método que busca classificar palavras, frases, ou mesmo parágrafos em categorias de conteúdo.

De acordo com Bardin (2002, p. 44) com a análise de conteúdo é possível ter uma melhor compreensão de uma comunicação ou discurso e extrair aspectos mais relevantes. Para tanto, é preciso tomar por base os objetivos específicos, leitura analítica, categorização e tratamento das informações.

Entre as técnicas de análise de conteúdo destaca-se a análise léxica que trabalha "diretamente no código: unidades semânticas e sintaxe (vocabulário, características gramaticais") e a análise categorial que trata do "desmembramento do discurso em categorias" (BARDIN, 2002, p. 80).

Em harmonia com a teoria de Bardin, a análise das respostas dos participantes às perguntas abertas foi feita com base nas técnicas léxica e categorial e seguiu o seguinte critério:

- Primeira Pergunta: Para você, o que é Qualidade de Vida no Trabalho?

Ocorreu uma análise das respostas apresentadas para identificar a existência de alinhamento com os conceitos apresentados na literatura de QVT e para verificar os temas mais recorrentes. 
- Segunda Pergunta: Qual a sua opinião sobre o programa de Qualidade de Vida no Trabalho do Banco do Brasil?

Com a técnica de análise léxica foi feita a identificação da opinião dos funcionários da Rede Entorno Norte seguido de um agrupamento de categorias, visando a apresentação dos resultados e também alguns comentários mais relevantes.

- Terceira Pergunta: Que sugestão você faria para contribuir coma qualidade de vida no seu ambiente de trabalho?

Por meio da técnica categorial foi feito a relação das sugestões mais relevantes com suas respectivas freqüências, temas mais recorrentes e exemplos de verbalização. 


\section{RESULTADOS E DISCUSSÃO}

Neste tópico é apresentado o diagnóstico e a análise da percepção pessoal dos funcionários do Banco do Brasil, lotados nas agências da Rede Entorno Norte com relação à Qualidade de Vida proporcionada pela organização a partir dos questionários devolvidos.

De início, é apresentado a análise das respostas às questões fechadas com base nas categorias conceituais de Walton (1973), adaptado aos 5 fatores da escala em processo de validação por Ribeiro (2010, p. 1-2) seguido da análise das respostas às questões abertas.

\section{1 - Fatores que Afetam a QVT}

Para verificar a percepção dos funcionários da Rede Entorno Norte do Banco do Brasil em relação aos fatores de QVT, o instrumento de pesquisa utilizado, elaborado por Patrícia Emanuele da Cruz Dias Ribeiro, em processo de validação, abordou 31 questões fechadas, baseadas na teoria de Walton (1973), enquadradas em cinco fatores: 1) Suporte à Execução do Trabalho; 2) Relacionamento; 3) Respeito Profissional; 4) Programas de Qualidade de Vida; e 5) Recompensas. Para avaliar as questões do instrumento foi utilizando uma escala intervalar, contínua, crescente e de cinco pontos $(0=$ Discordo, $1=$ Concordo pouco, $2=$ Concordo razoavelmente, 3 = Concordo muito, 4 = Concordo totalmente).

\subsection{1 - Suporte à Execução do Trabalho}

As questões enquadradas nesta categoria englobam os itens de número 1, 3, $4,7,12,13,21$ e 23 do instrumento de coleta de dados, apresentados na tabela 4, onde se constata uma concordância razoável com o suporte oferecido para a execução do trabalho (média: 2,21). O desvio padrão de 0,71 , revela um consenso entre os participantes da pesquisa.

O item que mais apresentou uma concordância satisfatória para a execução do trabalho foi o treinamento oferecido aos funcionários, com média de 2,9 (desvio padrão: 1) muito próximo de muita concordância (escala 3). 
Por outro lado, de forma negativa, o item 23 (sistema de comunicação claro) foi o que mais contribui na baixa concordância dos funcionários com média de 1,7 . Porém, o desvio padrão apresentado de 1 , revela falta de consenso entre os participantes.

Tabela 4 - Fator Suporte à Execução do Trabalho

\begin{tabular}{|c|c|c|c|c|c|c|c|}
\hline \multirow{2}{*}{ Item } & \multicolumn{5}{|c|}{ Escala } & \multirow{2}{*}{ Média } & \multirow{2}{*}{$\begin{array}{l}\text { Desvio } \\
\text { Padrão }\end{array}$} \\
\hline & 0 & 1 & 2 & 3 & 4 & & \\
\hline 1- Valoriza o trabalho dos funcionários & 6 & 16 & 49 & 16 & 5 & 2 & 0,9 \\
\hline 3- Dá liberdade $\mathrm{p} /$ o funci executar o trabalho c/ seu estilo pessoal & 4 & 28 & 34 & 24 & 2 & 1,9 & 0,9 \\
\hline 4- Fornece a infra-estrutura mat necessária $\mathrm{p} / \mathrm{a}$ execução do trabalho & 7 & 16 & 31 & 26 & 12 & 2,2 & 1,1 \\
\hline 7- Fornece um bom suporte tecnológico $\mathrm{p} /$ o desempenho do trabalho & 2 & 7 & 33 & 39 & 11 & 2,5 & 0,9 \\
\hline 12- Investe para que o ambiente físico de trabalho seja saudável & 11 & 20 & 33 & 22 & 6 & 1,9 & 1,1 \\
\hline 13- Assegura uma adequada jornada de trabalho & 12 & 14 & 30 & 27 & 9 & 2,1 & 1,2 \\
\hline 21- Oferece treinamento para os funcionários & 0 & 9 & 20 & 34 & 29 & 2,9 & 1 \\
\hline 23- Tem um sistema de comunicação claro & 13 & 21 & 36 & 22 & 0 & 1,7 & 1 \\
\hline Média e Des & drãc & Ger & $\mathrm{ral} \mathrm{d}$ & o Fa & & 2,21 & 0,71 \\
\hline
\end{tabular}

Fonte: Pesquisa de Campo

O fator Suporte à Execução do Trabalho aproxima-se da categoria de Walton Condições de Trabalho e segundo Pedroso e Pilati (2009, p. 33) deixar de minimizar os fatores que prejudicam a atuação do trabalhador como odores, ruídos ou poluição visual, pode prejudicar a sua atuação. O reflexo desse fator na QVT dos funcionários da Rede Entorno Norte do Banco do Brasil pode ser percebido pela média geral do fator de 2,21.

\subsubsection{Relacionamento}

O fator Relacionamento é composto pelas questões $8,9,17,17$ e 18 do instrumento de coleta de dados, conforme tabela 5 , onde fica evidenciado uma concordância mediana com o relacionamento existente na Rede de Agencia Entorno Norte (média: 2,3), com consenso entre os participantes da pesquisa tendo em vista o desvio padrão de 0,71. A média desse fator foi a segunda mais alta apurada entre as resposta do Instrumento de Pesquisa revelando tratar-se de um aspecto relevante para percepção dos participantes. 
O item que mais apresentou uma concordância satisfatória foi a exigência de respeito dos colabores para com seus superiores (item 18), com média de 2,8 (desvio padrão: 0,8) muito próximo de muita concordância (escala 3).

Percebe-se que a questão de relacionamento é prejudicada especialmente pelo papel dos superiores, tendo em vista que os participantes expressaram que concordam pouco com a existência de estímulo para o bom relacionamento entre chefias e funcionários, exigência de respeito dos superiores para com seus colaboradores e estímulo ao bom relacionamento entre chefias e funcionários (itens 9, 16 e 17) com médias de 2, 2,2 e 2,1, respectivamente. O cálculo do desvio padrão desses itens revela uma consenso mediano entre os participantes $(1,1 ; 0,9$ e 0,8$)$.

Tabela 5 - Fator Relacionamento

\begin{tabular}{|c|c|c|c|c|c|c|c|}
\hline \multirow{2}{*}{ Item } & \multicolumn{5}{|c|}{ Escala } & \multirow{2}{*}{ Média } & \multirow{2}{*}{$\begin{array}{l}\text { Desvio } \\
\text { Padrão }\end{array}$} \\
\hline & 0 & 1 & 2 & 3 & 4 & & \\
\hline 8- Possibilita relações sociais agradáveis entre os funcionários & 3 & 12 & 36 & 30 & 11 & 2,4 & 1 \\
\hline 9- Estimula o bom relacionamento entre chefias e funcionários & 11 & 16 & 34 & 23 & 8 & 2 & 1,1 \\
\hline 16- Exige respeito dos superiores para com seus colaboradores & 5 & 12 & 38 & 33 & 4 & 2,2 & 0,9 \\
\hline 17- Estimula o apoio dos superiores a seus colaboradores & 2 & 17 & 46 & 23 & 4 & 2,1 & 0,8 \\
\hline 18- Exige respeito dos colaboradores para com seus superiores & 0 & 5 & 27 & 42 & 18 & 2,8 & 0,8 \\
\hline Média $\epsilon$ & drãc & $\mathrm{Ge}$ & ral d & o Fa & & 2,3 & 0,71 \\
\hline
\end{tabular}

Fonte: Pesquisa de Campo

Para Waton (1973, apud FERNANDES, p. 49-52) relacionamento relaciona-se com auxílio recíproco, apoio sócio-emocional, abertura interpessoal e respeito às individualidades. A média do fator Relacionamento $(2,3)$ transparece claramente que os participantes da pesquisa não avaliam de forma positiva os aspectos considerados neste fator, especialmente quando considerado o relacionamento com os superiores.

\subsection{3 - Respeito Profissional}

Essa categoria é composta pelos itens $5,6,11,25,26,27,29$ e 30 do instrumento de coleta de dados, apresentados na tabela 6 , onde se verifica uma concordância razoável com o respeito profissional existente na Rede de Agência Entorno Norte (média: 2,15). O desvio padrão de 0,72 , revela um consenso entre os participantes da pesquisa. 
O apoio ao desenvolvimento pessoal (item 5) foi o que teve o maior peso no fator respeito profissional, com média de 2,6 na escala de concordância e desvio padrão de 0,9, muito próximo de muita concordância (escala 3).

$\mathrm{Na}$ contramão do fator relacionamento, está o item 6 (investe para que o funcionário não mude de empresa), com média de 1,4 e desvio padrão de 1,1 e item 11 (faz os funcionários se sentirem orgulhosos por trabalhar nela) com média de 1,8 e desvio padrão de 1. Esses dois itens são significativos na avaliação da percepção dos participantes tendo em vista que representam o $3^{\circ}$ e $5^{\circ}$ item com menor avaliação e que a instituição Banco do Brasil deveria se preocupar para promover a QVT.

Tabela 6 - Fator Respeito Profissional

\begin{tabular}{|c|c|c|c|c|c|c|c|}
\hline \multirow{2}{*}{ Item } & \multicolumn{5}{|c|}{ Escala } & \multirow{2}{*}{ Média } & \multirow{2}{*}{$\begin{array}{l}\text { Desvio } \\
\text { Padrão }\end{array}$} \\
\hline & 0 & 1 & 2 & 3 & 4 & & \\
\hline 5- Apóia o desenvolvimento pessoal & 2 & 10 & 21 & 45 & 14 & 2,6 & 0,9 \\
\hline 6- Investe para que o funcionário não mude de empresa & 22 & 27 & 26 & 15 & 2 & 1,4 & 1,1 \\
\hline 11- Faz os funcionários se sentirem orgulhosos por trabalhar nela & 11 & 23 & 33 & 21 & 4 & 1,8 & 1 \\
\hline 25- Respeita os direitos trabalhistas & 4 & 10 & 29 & 32 & 17 & 2,5 & 1 \\
\hline 26- Respeita a liberdade de expressão & 6 & 12 & 38 & 27 & 9 & 2,2 & 1 \\
\hline 27- Respeita a privacidade & 4 & 13 & 31 & 36 & 8 & 2,3 & 1 \\
\hline 29- Possibilita a realização profissional dos seus funcionários & 2 & 15 & 45 & 26 & 4 & 2,2 & 0,8 \\
\hline 30- Investe na segurança dos funcionários & 3 & 23 & 36 & 25 & 5 & 2,1 & 0,9 \\
\hline Média e D & drão & $\mathrm{Ge}$ & ral c & $\mathrm{o} F \mathrm{Fa}$ & & 2,15 & 0,72 \\
\hline
\end{tabular}

Fonte: Pesquisa de Campo

A categoria Constitucionalismo de Walton (1973 apud FERNANDES, p. 4952) aborda o fator Direito Trabalhistas, considerado como o cumprimento dos direitos trabalhistas assegurado por lei, como um dos elementos chaves para uma elevada Qualidade de Vida no Trabalho. Nesse quesito é possível perceber uma concordância por parte dos participantes quando consideraram esse fator com média de 2,5, segundo item melhor avaliado. Porém o investimento para que o funcionário não mude de empresa, de forma geral, foi avaliado de forma negativa pelos participantes. De acordo com a terceira dimensão do modelo de Hackman e Oldham (1975 apud CHIAVENATO, 2004, p. 292), Resultados Pessoais e de Trabalho o absenteísmo e a rotatividade baixa são indicadores da existência de QVT. 


\subsection{4 - Programas de Qualidade de Vida}

O fator Programa de Qualidade de Vida é composto pelos itens 14, 15, 20, 28 e 31 do instrumento de coleta de dados, conforme tabela 7, onde fica evidenciado uma concordância mediana (escala 2) na Rede de Agencia Entorno Norte (média: 2,33), com consenso entre os participantes da pesquisa tendo em vista o desvio padrão de 0,66. A média desse fator foi a mais alta apurada entre as resposta do Instrumento de Pesquisa revelando tratar-se de um aspecto relevante para percepção dos participantes.

Os itens que mais apresentaram uma concordância satisfatória foi a oferta de assistência médica e a oferta de bolsas de estudos para os funcionários (itens 14 e 20, com média de 3,3 e 3,1, respectivamente, os únicos que enquadram na escala de muita concordância (escala 3), com desvios padrão de 0,8 e 0,9, respectivamente, refletindo tratar-se de um consenso entre os participantes. Vale ressaltar que no fator assistência médica $51 \%$ dos participantes a concordaram totalmente com um indicador que o Banco do Brasil promove na QVT.

O fator Programas de Qualidade de Vida é visto de forma negativa especialmente na oferta de assistência odontológica (item 15), onde obteve uma média de 1,1. Porém o desvio padrão de 1,4 não reflete um consenso entre os participantes.

Tabela 7 - Fator Programas de Qualidade de Vida

\begin{tabular}{|c|c|c|c|c|c|c|c|}
\hline \multirow{2}{*}{ Item } & \multicolumn{5}{|c|}{ Escala } & \multirow{2}{*}{ Média } & \multirow{2}{*}{$\begin{array}{l}\text { Desvio } \\
\text { Padrão }\end{array}$} \\
\hline & 0 & 1 & 2 & 3 & 4 & & \\
\hline 14- Oferece assistência médica & 0 & 2 & 12 & 31 & 47 & 3,3 & 0,8 \\
\hline 15- Oferece assistência odontológica & 49 & 12 & 13 & 9 & 9 & 1,1 & 1,4 \\
\hline 20- Oferece bolsas de estudo para os funcionários & 1 & 4 & 16 & 35 & 36 & 3,1 & 0,9 \\
\hline 28- Promove eventos de recreação e lazer & 5 & 21 & 32 & 28 & 6 & 2,1 & 1 \\
\hline 31- Desenvolve programas de qualidade de vida no trabalho & 6 & 21 & 35 & 23 & 7 & 2 & 1 \\
\hline Médi & drãc & $\mathrm{Ge}$ & al d & $\mathrm{O} F$ & & 2,33 & 0,66 \\
\hline
\end{tabular}

Fonte: Pesquisa de Campo 


\subsection{5 - Recompensas}

Essa categoria é composta pelos itens 2, 10, 19, 22 e 24 do instrumento de coleta de dados, representados na tabela 8 , onde se verifica que os funcionários da Rede Entorno Norte não vêem a instituição Banco do Brasil promover esse fator. De forma geral a categoria obteve média de 1,76, menor de todas as categorias e o desvio padrão de 0,79 , o que revela um consenso entre os participantes da pesquisa.

O item 10 (paga salário justo) foi o que mais pesou para a baixa média do fator. Esse item teve uma média de 1,1 e 35 funcionários (38\%) discordaram totalmente (escala o) que o Banco do Brasil promova esse item. O desvio padrão desse item foi 1,1 apontando que não há uma concordância unânime.

Tabela 8 - Fator Recompensas

\begin{tabular}{|c|c|c|c|c|c|c|c|}
\hline \multirow{2}{*}{ Item } & \multicolumn{5}{|c|}{ Escala } & \multirow{2}{*}{ Média } & \multirow{2}{*}{$\begin{array}{l}\text { Desvio } \\
\text { Padrão }\end{array}$} \\
\hline & 0 & 1 & 2 & 3 & 4 & & \\
\hline 2- Recompensa a competência no trabalho & 6 & 14 & 49 & 19 & 4 & 2 & 0,9 \\
\hline 10- Paga salários justos & 35 & 23 & 24 & 9 & 1 & 1,1 & 1,1 \\
\hline 19- Reconhece os bons funcionários & 9 & 14 & 38 & 28 & 3 & 2 & 1 \\
\hline 22- Tem um sistema de promoção justo & 13 & 21 & 36 & 22 & 0 & 1,7 & 1 \\
\hline \multirow[t]{2}{*}{ 24- Reconhece os funcionários leais } & 10 & 16 & 38 & 25 & 3 & 2 & 1 \\
\hline & rão & Gera & al do & Fatc & & 1,76 & 0,79 \\
\hline
\end{tabular}

Fonte: Pesquisa de Campo

Muitos dos fatores abordados na categoria Recompensas podem ser enquadrados na categoria de Walton Compensação Justa e Adequada, a qual estabelece o critério de avaliar QVT pelo critério de remuneração adequada, considerada como aquela necessária para viver dignamente dentro das necessidades pessoais e dos padrões da sociedade em que vive. Walton argumenta que todos trabalham para "ganhar a vida" e a compensação que se obtém com esse trabalho é um aspecto fundamental quando se trata de analisar a QVT (WALTON, 1973 apud FERNANDES, 1996). Pela avaliação ao item 10 (paga salários justos) fica evidenciado a baixa concordância com a promoção de QVT nesse fator.

De forma geral, conforme Gráfico 1, os fatores de QVT, na percepção dos funcionários da Rede Entorno Norte do Banco do Brasil foram considerados de baixa concordância quanto a sua promoção no ambiente das agências pesquisadas. 
A avaliação do fator Programas de Qualidade de Vida foi o que alcançou a melhor avaliação $(2,33)$, seguido do Relacionamento $(2,30)$, porém, suas baixas médias indicam que ainda resta um longo caminho a percorrer pela instituição a fim de alcançar uma melhor avaliação por parte do corpo de funcionários das agências pesquisadas.

Os piores fatores, Recompensas e Respeito profissional indicam que a questão dos salários e o relacionamento com chefia precisam sofrer uma significativa melhora para proporcionar uma melhora na avaliação da QVT na Rede Entorno Norte.

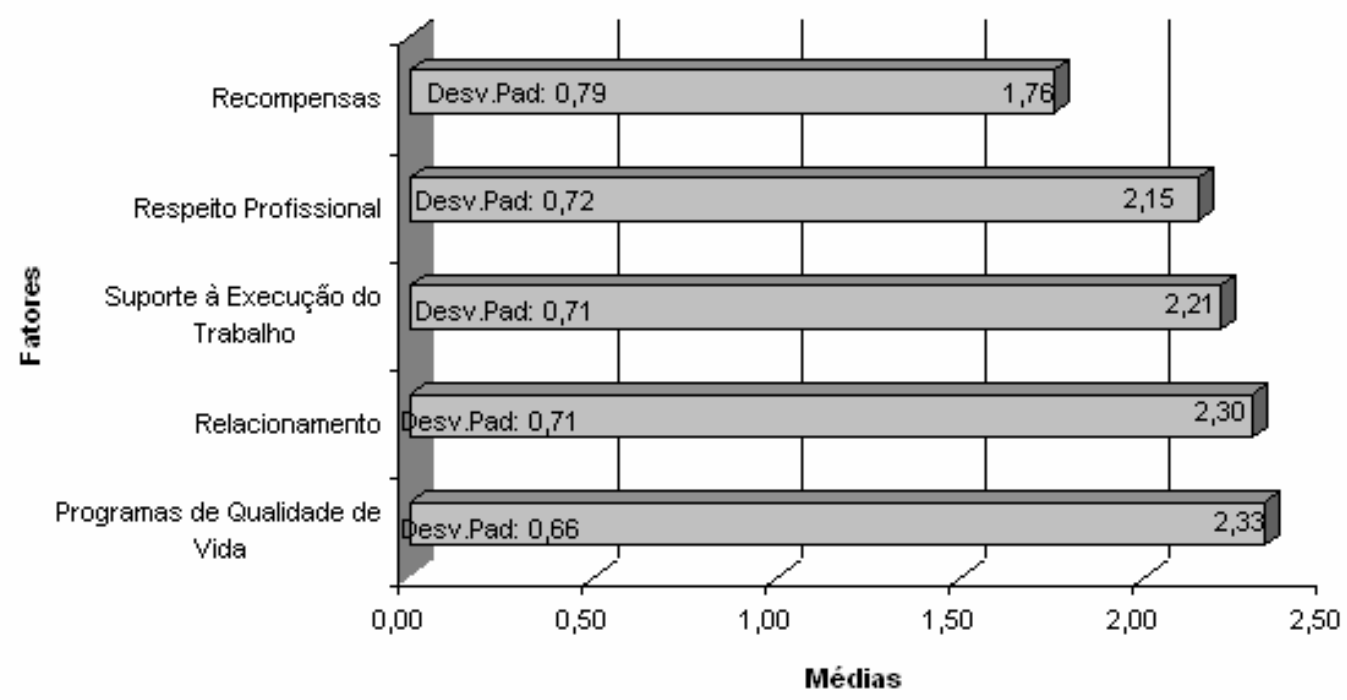

Gráfico 1: Média dos Fatores que Influenciam na QVT da Rede Entorno Norte (Escala de 0 a 4) Fonte: Pesquisa de Campo

\section{2 - Perguntas Abertas}

A pesquisa contemplou também questões abertas que objetivavam extrair dos participantes o conceito de qualidade de vida no trabalho, avaliação quanto ao programa de QVT do Banco do Brasil e sugestões.

\subsection{1 - O que é Qualidade de Vida no Trabalho?}

A pergunta 01 da parte II do Instrumento de Coleta de Dados: Para você, o que é Qualidade de Vida no Trabalho?, constante do Apêndice D, visou atingir o objetivo de conhecer a percepção dos entrevistados sobre o conceito de qualidade de vida 
no trabalho. A pergunta foi respondida por $87(94,6 \%)$ participantes e $5(5,4 \%)$ deixaram em branco (participantes de nr. 24B, 32B, 80D, 87F, 92F).

As respostas apresentadas, conforme exemplificado abaixo, mostram um alinhamento com os conceitos da literatura que associam QVT a humanização do trabalho, conciliação dos interesses dos indivíduos e a organização, melhorias e inovações gerenciais, tecnológicas e estruturais dentro e fora do ambiente de trabalho, benefícios organizacionais, compreendidos não apenas a questão salarial (WALTON, 1973, apud TOLFO; PISCININI, 2001, p. 167; FERNANDES, 1996, p. 43; ALBUQUERQUE; LIMONGI-FRANÇA, 1998, p. 44; CUNHA, 2009, p. 226-227), conforme pode ser observado pelos comentários a seguir:

"Boas instalações, equipamentos de informática. Ter condições de dar um bom atendimento aos nossos clientes" (participante 5A).

"Um ambiente de trabalho confortável, amigável, com boa remuneração além de uma ótima possibilidade de melhoria para o funcionário" (participante 6A).

"É ter um ambiente adequado para as realizações das tarefas, ter recursos necessários para a efetivação, poder se programar e ter o tempo ou prazos adequados, ter respeito entre os colegas independente de posições hierárquicas, ter reconhecimento do trabalho realizado e incentivo para promoções bem definidos" (participante 33B).

"Bom relacionamento entre colegas, boa remuneração e conciliação entre carreira e família" (participante 10A).

"O ambiente e as pessoas em consonância" (participante 16A).

"É trabalhar num ambiente agradável, com bom relacionamento e salário digno" (participante 59C).

"Trabalhar em paz" (participante 22B).

"Respeito e lealdade entre os colegas. Bom clima organizacional" (participante 48C).

"Relação entre todos os funcionários com igualdade, tanto nas tarefas como na renda" (participante 62C).

"É um estado de bem estar físico, mental e social e não só a ausência de doenças oriundas do estresse ocupacional" (participante 71D).

"É um conjunto de ações que envolvem diagnósticos e implantação de melhorias e inovações gerenciais, tecnológicas e estruturais na empresa" (participante 72D). 
"Momentos de relaxamento, bom clima organizacional, valorização dos funcionários, reconhecimento de competências" (participante 86E).

"Salário digno, valorização do trabalhador" (participante 1A).

"Satisfação entre a remuneração e as exigências do cargo" (participante 44C).

"Salário Justo, ambiente adequado, valorização profissional, diminuição da pressão e do assédio moral" (participante 45C)

Nas respostas apresentadas os participantes relacionaram QVT com mais freqüências aos seguintes temas:

- Condições de trabalho (freqüência: 34) - envolvendo a infra-estrutura física, equipamentos disponíveis para a execução das tarefas, móveis adequado, número de funcionários suficientes de acordo com a demanda do trabalho e respeito à jornada de trabalho.

- Relacionamento (freqüência: 12) - englobando o relacionamento entre colegas e entre chefia e subordinados, clima organizacional e confiança na equipe;

- Respeito Profissional (freqüência: 20) - referindo-se ao desenvolvimento pessoal, políticas de treinamento, valorização do empregado, ascensão profissional, menor pressão dos superiores e respeito às qualidades individuais.

- Recompensas (freqüência: 16) - envolvendo a questão do salário compatível com as atividades realizadas e reconhecimento.

\subsection{2 - Opinião sobre o Programa de Qualidade de Vida no Trabalho do Banco do Brasil}

A pergunta Qual a sua opinião sobre o programa de Qualidade de Vida no Trabalho do Banco do Brasil?, constante na pergunta 02 da parte II do Instrumento de Coleta de Dados teve por o objetivo avaliar a percepção dos entrevistados sobre o programa de QVT do Bando do Brasil. A pergunta foi respondida por 86 $(93,4 \%)$ participantes e $6(6,6 \%)$ deixaram em branco (participantes de nr. 24B, 30B, 35B, 37B, 80D, 87F), conforme Apêndice E.

Foi possível enquadrar as respostas apresentadas pelos participantes basicamente em quatro categorias: bom, regular, existe, mas não funciona e desconhece, conforme tabela 9.

Para 13,95\% dos participantes (freqüência: 12) o programa de QVT é bom, para 32,56\% (freqüência: 28) é regular, para 34,88\% (freqüência: 30 ), grande maioria, existe, mas não funciona e 18,61\% (freqüência: 16) não possuem 
conhecimento sobre o programa.

As respostas apresentadas estão de acordo com a análise dos fatores de QVT que demonstram uma percepção de baixa evidência de QVT na Rede Entorno Norte. Chama atenção o fato de $18 \%$ dos funcionários não terem conhecimento sobre o programa.

Tabela 9: Opinião Sobre o Programa de Qualidade de Vida do Banco do Brasil na percepção dos funcionários da Rede Entorno Norte

\begin{tabular}{|l|r|r||}
\hline Opinião sobre o Programa de QVT do BB & Freqüência & Percentual \\
\hline Bom & 12 & 13,95 \\
\hline Regular & 28 & 32,56 \\
\hline Existe mas não funciona & 30 & 34,88 \\
\hline Desconhece & 16 & 18,61 \\
\hline
\end{tabular}

Fonte: Pesquisa de Campo

Algumas das respostas apresentadas pelos participantes foram:

"Boa iniciativa a fim de proporcionar melhores condições de trabalho para o funcionário" (participante $2 \mathrm{~A}$ );

"Muito bom. Poucas empresas têm condições de oferecer o que o banco nos oferece" (participante 5A).

"Esta boa, porém tem condições de melhorar" (participante 31B).

"Ainda está começando, precisa melhorias principalmente em relação a verbas para ser investidas na qualidade de vida dos empregados" (participante 14A).

"Entendo que ainda são ações tímidas que pouco contribuem com a melhoria. Há muito ainda a avançar" (participante 66C).

"Satisfatório. Além dos programas próprios das agências, deveriam ter convênios regionais e nacionais contemplando a QVT" (participante 75D).

"É interessante, mas considerando a complexidade das atividades desenvolvidas acredito que deveria ter maiores incentivos para esportes e práticas de atividades físicas" (participante 85E).

"O programa é bom, porém não funciona na pratica devido às metas e poucos funcionários" (participante 19A)

"Qualquer iniciativa do tipo destinação de verba, cai por terra devido à pressão por metas e assédio moral" (participante 45C). 
"Não funciona. O programa é lembrando algumas vezes durante o ano, não tem continuidade de processo" (participante 81D).

\subsection{3 - Sugestões para contribuir com a Qualidade de Vida no Trabalho}

A terceira pergunta da parte II do Instrumento de Coleta de Dados foi: Que sugestão você faria para contribuir com a qualidade de vida no seu ambiente de trabalho?

A pergunta foi respondida por 78 (85\%) participantes e 14 (15\%) deixaram em branco (participantes de nr. 2A, 5A, 12A, 16A, 22B, 24B, 31B, 32B, 34B, 35B, 41B, 56C, 80D, 87F), conforme apêndice $F$.

Entre as sugestões apontadas houve um maior destaque para:

- Melhorar as instalações físicas (freqüência: 18), que apresentaram as seguintes sugestões:

- Melhorar a climatização do ambiente;

- Diminuir o ruído;

- Fornecimento de equipamentos adequados para a execução das tarefas;

- Melhor ambiência;

- Móveis ergonômicos;

- Melhorar a iluminação.

Exemplos de verbalização:

"Melhores instalações principalmente contra ruídos e temperatura" (participante 3A)

"Especificamente na minha agencia o ambiente físico em si é um dos fatores que mais comprometem o rendimento dos funcionários, por isso minha sugestão seria investir no ambiente físico" (participante 18A).

- Atividades de QVT (freqüência: 17), aqui identificado as seguintes atividades:

- Implantar confraternizações;

- Realização de eventos fora do ambiente de trabalho;

- Ginástica laboral;

- Momentos de descontração durante o expediente;

- Criação de espaço de relaxamento;

- Realização de atividades esportivas. 
Exemplos de verbalização:

"Maior convívio entre membros da equipe, principalmente em eventos fora do ambiente de trabalho" (participante 14A).

"Realizar reuniões comemorativas extra-banco com os colegas de trabalho" (participante 23B).

"Criação de espaço "zen" para descanso e relaxamento dos funcionários, visto que a maioria não mora no município" (participante 75D).

"Estimular atividades e esportes em grupo contribuindo com o bem estar físico e mental" (participante 85E).

- Contratar mais funcionários (freqüência: 14)

Exemplo de Verbalização:

"Maior quantidade de funcionários" (participante 83E).

"Aumentar a quantidade de funcionários para dar melhores condições de trabalho e de atendimento para os clientes" (participante 93F).

- Respeito por parte dos superiores hierárquicos (freqüência: 9), envolvendo os seguintes temas:

- Coibir o assédio Moral;

- Respeito por parte dos superiores;

- Respeito da instituição aos funcionários (valorização);

- Ética por parte dos Superiores.

Exemplos de verbalização:

"Alteração no tratamento das lideranças do banco em relação aos subordinados. Fiscalização pelo banco, das cobranças excessivas dos gestores sobre a equipe" (participante 11A).

"Criação de normas de conduta para inibir o assédio moral" (participante 28B).

"Mais respeito da instituição com relação aos funcionários" (participante 38B).

- Melhorar a capacitação (freqüência: 6), englobando as seguintes sugestões específicas:

- Conscientizar sobre a importância do papel individual dentro da organização;

- Existência de orientador;

- Melhorar os processos de treinamento; 
- Mais tempo para aprimoramento pessoal;

Exemplos de Verbalização:

"A capacitação e o treinamento adequado para todos os funcis e colaboradores, onde todos estão cientes de seu papel na organização" (participante $7 A)$.

"Toda agencia ter um orientador" (participante 8A).

"Melhoria nos processos de treinamentos auto-instrucionais" (participante 43B).

- Jornada de 6 horas (freqüência: 6 )

Exemplos de Verbalização:

"Quem sabe a implantação das 6 horas de trabalhos para comissionados" (participante 13A);

"Jornada de trabalho de 6 horas, tempo para treinamentos e estudos" (participante 42B)

- Metas (freqüência: 6), envolvendo os seguintes temas:

- Relacionar as metas ao programa de QVT;

- Menor quantidade de serviço;

- Diminuir as metas;

Exemplos de Verbalização:

"Conjugar as metas com o programa QVT" (participante 19A);

"Diminuição da quantidade de serviço e menor pressão pelo cumprimento de Metas" (participante 25B).

"Menos metas abusivas, incompatíveis com a realidade de trabalho, mais valorização dos funcionários" (participante 60C)

- Melhorar os Salários (freqüência: 5)

Exemplos de Verbalização:

"Aumento Salarial" (participante 49C)

"Melhores Salários" (participante 53C).

Nas sugestões, um fato que chama atenção é que embora o fator Recompensa tenha recebido a menor avaliação por parte dos funcionários da Rede 
Entorno Norte, as sugestões de melhoria não se concentram nesse fator e sim nas instalações físicas. A importância do ambiente físico na QVT é natural tendo em vista que ele tem o poder de envolver o funcionário enquanto este desenvolve suas atividades na organização, sendo percebido como algo muito importante para a satisfação (MARTINS, 2003, p. 11). 


\section{CONCLUSÕES E RECOMENDAÇÕES}

A presente pesquisa foi proposta com o objetivo de conhecer, a partir da percepção dos funcionários das agências da Rede Entorno Norte do Banco do Brasil, o conceito de QVT mentalizado pelos participantes da pesquisa, as ações adotadas pelo Banco do Brasil para promover a qualidade de vida no ambiente de trabalho, as sugestões dos funcionários e a percepção em relação às ações de QVT, tomando por base a teoria de Walton (1973).

Para atingir os objetivos propostos foi de importância o referencial teórico baseado nas proposições de Walton (1973) e também a metodologia utilizada que teve uma abordagem tanto qualitativa quanto quantitativa, através de um Instrumento de Pesquisa que contou com perguntas abertas e fechadas, envolvendo os seguintes fatores 1) Suporte à Execução do Trabalho; 2) Relacionamento; 3) Respeito Profissional; 4) Programas de Qualidade de Vida; e 5) Recompensas.

Os dados coletados permitiram chegar às seguintes conclusões:

$1^{\circ}$ - Os funcionários da Rede Entorno Norte possuem um conceito de QVT alinhado com as definições abordados pelos principais autores do assunto, relacionando-o, de forma mais incisiva, com as condições de trabalho encontradas nas agências, envolvendo principalmente a infra-estrutura física, equipamentos disponíveis para a execução das tarefas, móveis adequado, número de funcionários suficientes de acordo com a demanda do trabalho e respeito à jornada de trabalho.

$2^{\circ}$ - No Banco do Brasil existe uma clara preocupação com a temática qualidade de vida no ambiente de trabalho expresso principalmente pela existência de um programa de QVT lançado em julho de 2007 que tem como objetivo promover a qualidade de vida no trabalho dos funcionários, colaboradores, com foco no estímulo aos cuidados com a saúde e na adoção de hábitos saudáveis, ancorado em ações de comunicação interna, educação experimentação e suporte, onde se destacam mais de onze ações concretas.

$3^{\circ}$ - O programa de QVT promovido pelo Banco do Brasil não esta atingindo o objetivo proposto na Rede de Agencias Entorno Norte já que a maioria dos participantes (34,88\%) expressaram que o programa existe, mas não funciona, $32,56 \%$ o consideram regular, $18,61 \%$ não possuem conhecimento sobre o programa. Apenas $13,95 \%$ o consideram bom. 
$4^{\circ}$ - As sugestões oferecidas pelos participantes estão alinhadas com o conceito que possuem de QVT e se concentram em questões relacionadas com a melhoria das instalações físicas, realização de atividades de QVT, contratação de mais funcionários, respeito por parte dos superiores hierárquicos, melhorar a capacitação, jornada de 6 horas, diminuição das metas e melhores salários.

$5^{\circ}$ - A percepção dos participantes em relação às ações de QVT promovidas pelo Banco do Brasil, apurada com base na teoria de Walton (1973) apontam que os participantes concordam razoavelmente que existe a promoção de QVT. Os fatores que foram considerados mais positivos, na ordem, foram: Programas de Qualidade de Vida, Relacionamento e Suporte à Execução do Trabalho. E os mais negativos foram Recompensas e Respeito Profissional.

Embora se possa considerar que a pesquisa atingiu o objetivo proposto podese mencionar uma limitação na utilização da escala intervalar contínua de cinco ponto ( 0 a 4) que levou muitos a se posicionarem no ponto neutro (2) e à ausência de outras pesquisas que tenham feito uso dos cinco fatores utilizados para fins de comparação de resultados e busca de referencial teórico.

Outra limitação desta pesquisa foi o pouco aprofundamento na análise dos dados coletados em virtude da demora na definição do instrumento de QVT a ser utilizado, que na maioria dos eixos temáticos ocorreu em maio/2010, enquanto que o de QVT foi disponibilizado apenas no final de setembro/2010, pelo atraso na coleta dos dados ocasionado pela greve dos bancários, que se entendeu de 28/09 a 13/10 e pela dificuldade de encontrar um horário que permitisse aplicar o instrumento de pesquisa aos participantes ao mesmo tempo já que os funcionários do Banco do Brasil possuem horário de entrada ao trabalho diferenciado e passam a maior parte da carga horária realizando o atendimento ao cliente, com pouca liberdade para outros assuntos.

Após a coleta dos dados, outra limitação que prejudicou o aprofundamento na pesquisa, reduzindo o tempo de análise dos dados coletados foi a disponibilização tardia nos fatores QVT abordado pelo Instrumento de Coleta de Dados, em processo de validação, que ocorreu apenas no dia 25/10, quando, de acordo com o cronograma, já era para esta na fase das conclusões e considerações finais (18/10 a 31/10/2010).

A pesquisa apresentada não tem a pretensão de esgotar o assunto, nem limitar a possibilidade de um estudo mais apurado. Estudos futuros podem ser 
realizados com a sugestão de verificar a correlação entre as variáveis de QVT e gênero, entre QVT e a função exercida ou em comparar a QVT das várias agencias participantes do público desta pesquisa. Pode-se ainda realizar a pesquisa com uma escala de seis pontos objetivando diminuir a possibilidade dos participantes se manterem em um ponto neutro (MATTAR, 2005, P. 23).

De relevância seria ainda a possibilidade da realização de uma nova pesquisa junto a outros grupos de participantes para verificar a validade do Instrumento de Coleta de Dados, em processo de validação, com o objetivo de confirmar ou refutar os resultados aqui obtidos nesta pesquisa.

Concluindo é possível afirmar que o Banco do Brasil tem um programa definido de QVT e investe em práticas de QVT, porém os funcionários da Rede Entorno Norte não possuem essa percepção, tendo em vista que as respostas dos participantes e a escala utilizada indicaram que concordam razoavelmente que existe QVT no ambiente de trabalho das agências pesquisadas.

Porém, espera-se que com os resultados desta pesquisa que serão entregues à Gerência das agências envolvidas, que não esgotaram o assunto pesquisado, possibilite um diagnóstico e a criação de planos de ação que permitam ajustar continuamente a relação entre o sujeito-organização (COELHO, 2004, p. 14). Entre as ações que poderão ser adotadas será feito a sugestão de maior divulgação do programa de QVT do Banco do Brasil, visto que 18\% dos participantes afirmaram não conhecer o programa, e o estudo das sugestões apresentadas, principalmente na questão da melhoria das instalações físicas, aqui compreendido a questão de climatização, ruído, equipamentos adequados para a execução da tarefa, ambiência, iluminação e móveis ergonômicos, já que o conceito de QVT dos participantes e as sugestões apresentadas se concentram nesta temática e a implementação não demandará muito esforço. 


\section{REFERÊNCIAS}

ALBUQUERQUE, L. G.; LIMONGI-FRANÇA, A. C. Estratégias de gestão de pessoas e gestão da qualidade de vida no trabalho: o stress e a expansão do conceito de qualidade total. Revista de Administração, São Paulo, v. 33, n. 2, p. 40-51, Abr.Jun. 1998.

BARDIN, L. Análise de conteúdo. Trad. Luís Antero Reto e Augusto Pinheiro. Lisboa: Edições 70, 2002

BOM SUCESSO, E. P. Qualidade de Vida no Trabalho. São Paulo: Duya, 1998.

CHIAVENATO, I. Gestão de pessoas: o novo papel dos recursos humanos nas organizações. Rio de Janeiro: Campus, 2004.

COELHO, C. L. M. Clima organizacional e stress numa empresa de comércio Varejista. Revista Psicologia: Organizações e Trabalho, Brasília Vol. 4, No 1, p. 11-36, jan.-jun., 2004.

CUNHA, K. C. C. Gestão da qualidade de vida no trabalho em instituições de saúde. Organizadores: ROSSI, A. M.; QUICK, J. C.; PERREWÉ, P. L., Stress e qualidade de vida no trabalho: o positivo e o negativo. São Paulo: Atlas, 2009.

ELGENNENI, S. M. M.; CRUCIOL, C. V. Assédio moral no trabalho: implicações individuais, organizacionais e sociais. Revista Psicologia: Organizações e Trabalho, Brasília Vol. 9, No 1, p. 68-85, jan.-jun., 2009.

FARIA, G. S. S.; RACHID, A. Equilíbrio trabalho e família: os significados para os bancários. Revista Psicologia: Organizações e Trabalho, Brasília, vol. 7, nr. 1, p. 81-106, jan.-jun., 2007.

FERNANDES, E. C. Qualidade de vida no trabalho: como medir para melhorar. $2^{\mathrm{a}}$ Ed. Salvador: Casa da Qualidade, 1996.

GARCIA, E. O. P. Estudo de caso exploratório sobre qualidade de vida no trabalho de funcionários públicos. Revista Organizações em Contexto, São Paulo, Ano 3, n. 5, jan.-jun., 2007. 
LIMONGI-FRANÇA, A. C. Promoção de saúde e qualidade de vida no trabalho: o desafio da gestão integrada. Organizadores: ROSSI, A. M.; QUICK, J. C.;

PERREWÉ, P., Stress e qualidade de vida no trabalho: o positivo e o negativo. São

Paulo: Atlas, 2009.

LIMONGI-FRANÇA, A. C.; KANIKADAN, A. Y. S. A construção de um instrumento de coleta de dados a partir do modelo de indicadores biopsicossocial e organizacional BPSO-96 e do modelo de competências do bem-estar - BEO sobre gestão de qualidade de vida no trabalho. Revista Eletrônica de Administração, São Paulo, vol 12, n. ${ }^{\circ} 6$, nov.-dez., 2006.

MARTINS, A. M. S. Programas de qualidade de vida, satisfação no trabalho e comprometimento organizacional. In: Encontro da Associação Nacional de Pósgraduação em Administração, 23., 2003, Atibaia. Anais... Atibaia: ANPAD, 2003.

MATIAS-PEREIRA, J. Metodologia científica: manual de pesquisa científica. Brasília: FACE/CEAD/UnB, 2006.

MATTAR, F. N. Pesquisa de marketing. 6a edição. São Paulo: Atlas, 2005.

MORAES, L. F. R.; MARQUES, A. L.; KILIMNIK, Z. M.; LADEIRA, M. B. Recursos humanos. In: Anais do $19^{\circ}$ ENANPAD, set./1995, v. 1, n. 09. p. 177-180.

NADLER, D. A.; LAWLER, E.E. Quality of work life: perspectives and directions. Organizational dynamics. Organizational dynamics, v. 11, n. 3, p. 2030, 1983.

NISHIMURA, A. Z. F. C. Produção bibliográfica da qualidade de vida no trabalho. Piracicaba: UNIMEP, 2008. 280 p. Dissertação/Mestrado em Administração. Faculdade de Gestão e Negócios - Universidade Metodista de Piracicaba.

OLIVEIRA, J. A. Qualidade de Vida dos empregados x lucro: há coerência? Revista Tendências do Trabalho, nr. 286, p.22, junho de 1998.

PEDROSO, B.; PILATTI, L. A. Notas sobre o modelo de qualidade de Vida no trabalho de Walton: uma revisão literária. Conexões, v. 7, n. 3, p. 28 -43, 2009.

RIBEIRO, P. E. C. D. Escala de Qualidade de Vida no Trabalho (manuscrito não publicado). Brasília: UnB, 2010. 
RODRIGUES, M. V. C. Qualidade de vida no trabalho: evolução e análise no nível gerencial. Petrópolis, RJ: Vozes, 1994.

ROESCH, S. M. A. Projeto de estágio e pesquisa em administração: guia para estágios, trabalho de conclusão, dissertações e estudos de caso. $3^{a}$. Ed. São Paulo, Atlas, 2005.

SILVA, L. V. Qualidade de vida do trabalhador na Springer Carrier: uma análise dos programas e políticas da empresa num contexto de flexibilização do trabalho. Porto Alegre: UFRGS, 2001. 161 P. Dissertação/Mestrado em Administração. Universidade Federal do Rio Grande do Sul.

SIQUEIRA, M. M. M. S.; COLETA, J. A. D. Metodologia da investigação da qualidade de vida no trabalho. Psicologia do Trabalho, Rio de Janeiro, v. 41, n. 3, p.51-66, 1989.

TIMOSSI, L. S. et al. Adaptação do modelo de Walton para avaliação da qualidade de vida no trabalho. Revista da Educação Física, v. 20, n. 3, p. 395-405, 2009.

TAMAYO, A. Valores organizacionais: sua relação com satisfação no trabalho, cidadania organizacional e comprometimento afetivo. Revista de Administração, São Paulo, V.33, n.3, p.56-63, jul.-set., 1998.

TOLFO, S. R; PICCININI, V. C. As melhores empresas para trabalhar no Brasil e a qualidade de vida no trabalho: disjunções entre a teoria e a prática. RAC - Revista de Administração Contemporânea, v. 5, n. 1, P.165-193, jan.-abr., 2001.

VERGARA, S. C.. Projetos e relatórios de pesquisa em administração. 11. ed. São Paulo: Atlas, 2009. 


\section{APÊNDICES}

\section{Apêndice A - Carta de Encaminhamento à Empresa}

VALDIR VANIQUE DE SANTANA

QUADRA 12 MR 12 CASA 35

SETOR NORTE - PLANALTINA GOIAS.

Brasília, de de 2010.

BANCO DO BRASIL S.A. AGÊNCIA:

\section{Prezado(a) Senhor(a):}

Sou aluno da Graduação em Administração à Distância da Universidade de Brasília e estou desenvolvendo uma pesquisa sobre QUALIDADE DE VIDA NO TRABALHO NO AMBIENTE DAS AGÊNCIAS DO BANCO DO BRASIL DA REDE ENTORNO NORTE.

Diante do interesse que tem surgido na literatura científica por esse tema e da necessidade prática de se compreender melhor a realidade das organizações brasileiras, gostaria de solicitar a colaboração do Banco do Brasil com esse estudo, no sentido de autorizar a realização da coleta de dados junto a seus funcionários. Para isso, o pesquisador responsável aplicará um questionário que tem duração média de preenchimento de 10 minutos, em horário e data que poderão ser negociados de forma a não interferir na atividade profissional dos participantes. Meu nome é Valdir Vanique de Santana e sou o pesquisador responsável. Estaria á disposição para fornecer mais informações e esclarecer dúvidas por meio dos telefones 61- 3637-4006 e 61-8457-5234. e pelo e-mail valdirvanique@yahoo.com.br

Agradeço desde já a atenção e aguardo retorno quanto à viabilidade deste trabalho.

$$
\text { Atenciosamente, }
$$




\title{
Apêndice B - Carta de Encaminhamento ao Participante
}

\author{
VALDIR VANIQUE DE SANTANA \\ QUADRA 12 MR 12 CASA 35 \\ SETOR NORTE - PLANALTINA GOIAS. \\ Brasília, \\ de \\ de 2010.
}

Prezado Colega,

Estou me dirigindo a você para solicitar a sua colaboração no sentido de responder ao questionário em anexo com o objetivo de conhecer a percepção do funcionário do Banco do Brasil da Rede Entorno Norte, referente ao tema Qualidade de Vida No Trabalho. Esta pesquisa faz parte de um trabalho de conclusão de curso de graduação da Universidade de Brasília.

A sua participação é voluntária. Se você decidir participar ou não, isto não afetará a sua relação atual ou futura com a equipe de pesquisa ou com a instituição. Gostaria que você se sentisse inteiramente à vontade para dar suas opiniões

Se você aceitar participar, peço que responda ao questionário anexo que terá duração de aproximadamente 10 minutos. Os participantes não serão identificados e os dados fornecidos serão utilizados apenas para fins de pesquisa. Não escreva seu nome em qualquer lugar do questionário e se possível, não deixe nenhuma questão em branco.

Qualquer dúvida, entre em contato comigo pelos telefones e e-mails abaixo ou por Nota Pessoal.

Agradeço desde já a sua colaboração!

Valdir Vanique de Santana

Matrícula: 9.434.959-2

Email: f9434959@bb.com.br e valdirvanique@yahoo.com.br

Telefone: 8457-5234 


\section{Apêndice C - Instrumento de Coleta de Dados - Partes I e II INSTRUMENTO DE COLETA DE DADOS}

\section{I - PARTE:}

Agência:

Data:

\section{Faixa etária:}

( ) 18 a 25 anos ( ) 26 a 35 anos ( ) 36 a 45 anos ( ) acima de 46 anos Sexo:
( ) Feminino
( ) Masculino

\section{Estado civil:}

( ) Solteiro/Viúvo/Divorciado/Separado

( ) casado/União Estável

\section{Escolaridade:}
( ) Ensino Médio
( ) Graduação Incompleta
( ) Graduação Completa
( ) Pós-Graduação/Mestrado/Doutorado

II - PARTE

01- Para você, o que é Qualidade de Vida no Trabalho?

02- Qual a sua opinião sobre o programa de Qualidade de Vida no Trabalho do Banco Brasil?

03- Que sugestão você faria para contribuir com a qualidade de vida no seu ambiente de trabalho? 


\section{Apêndice D - Respostas à pergunta: Para você, o que é Qualidade de Vida no Trabalho?}

\section{Participante Pergunta: Para você o que é Qualidade de Vida no Trabalho?}

$1 \mathrm{~A}$

$2 \mathrm{~A}$

$3 \mathrm{~A}$

$4 \mathrm{~A}$

$5 \mathrm{~A}$

$6 \mathrm{~A}$

$7 \mathrm{~A}$

8A

$10 \mathrm{~A}$

$11 \mathrm{~A}$

$12 \mathrm{~A}$

$13 \mathrm{~A}$

$14 \mathrm{~A}$

$15 \mathrm{~A}$

$16 \mathrm{~A}$
Salário digno, valorização do trabalhador.

Ambiente onde o profissional pode desempenhar sua função sem comprometer sua saúde.

Respeito entre as pessoas, condições de trabalho no mesmo nível das exigências, clara política de ascensão profissional.

Ter todo suporte para realização do meu trabalho. Me sentir valorizada e obter reconhecimento.

Boas instalações, equipamentos de informática. Ter condições de dar um bom atendimento aos nossos clientes.

Um ambiente de trabalho confortável, amigável, com boa remuneração além de uma ótima possibilidade de melhoria para o funcionário.

Ambiente físico saudável, favorável, jornada de trabalho compatível com atividade e motivação entre os companheiros de trabalho.

Valorização, condições de trabalho. Móveis adequados a função, treinamento.

Bom relacionamento entre colegas, boa remuneração e conciliação entre carreira e família.

Trabalhar com alegria, ter a possibilidade de cumprir as metas e objetivos propostos. Ter uma boa relação com os colegas.

É trabalhar sem stress, cobranças de metas, filas intermináveis etc.

Disponibilidade de tempo para trabalho para cuidar de assuntos pessoais, particulares.

É o empregador oferecer beneficio de remuneração condizente com cargo/função do empregado, e dar condições de clima organizacional para que o mesmo ambiente de trabalho e convívio com os membros da equipe.

Trabalhar em uma empresa que fornece conforto, material de trabalho, estrutura física.Empresa que se preocupa com o bem estar físico e psicológico dos funcionários.

O ambiente e as pessoas em consonância. 


\section{Participante Pergunta: Para você o que é Qualidade de Vida no Trabalho?}

$17 \mathrm{~A}$

É a empresa te proporcionar condições de ascensão profissional e pessoal, suprindo as suas necessidades.

É quando a empresa oferece condições dignas e justas de trabalho, 18A quando valoriza o que há de bom em cada empregado, valorizando as qualidades de cada um.

Ambientes e condições que gerem satisfação em trabalhar na empresa.

Ter ferramentas para poder trabalhar bem como bons 20B equipamentos, sistema operacional e quantidade de funcionários adequada.

21B Satisfação com a ambiência, colegas e empresa.

22B Trabalhar em paz

23B Um trabalho que valorize o bem estar físico, mental e social do empregado.

25B É ter condições adequadas de trabalho

26B É ter um bom clima organizacional entre as pessoas, com respeito e comprometimento de todos

27B

Gostar do que faz, ter condições de trabalho, ter metas compatíveis com o volume de serviço.

Condições descentes de trabalho, remuneração condizente com as atribuições.

Trabalhar em equipe, ter horário de almoço mais prolongado, mais abonos, menos sobrecarga de trabalho.

30B Satisfação entre a remuneração e as exigências do cargo

31B trabalhar com tranqüilidade e conforto, e quando a equipe interage com os demais colegas.

É ter um ambiente adequado para as realizações das tarefas, ter recursos necessários para a efetivação, poder se programar e ter o 33B tempo ou prazos adequados, ter respeito entre os colegas independente de posições hierárquicas, ter reconhecimento do trabalho realizado e incentivo para promoções bem definidos.

É ter condições adequadas para que o funcionário possa se desenvolver sem pressão, respeitando as individualidades de cada 34B um. 


\section{Participante Pergunta: Para você o que é Qualidade de Vida no Trabalho?}

$35 \mathrm{~B}$

É ter uma estrutura adequada que cria condições ao indivíduo para desenvolver o seu potencial. Onde privilegie o bem estar físico e mental.

36B

É ter um ambiente de trabalho agradável, com mobiliário e material adequado ao desenvolvimento de sua função, assistência médica e odontológica, trabalho em equipe com funções bem delimitadas

Carga horária reduzida, espaço para descanso durante a jornada de trabalho com sofá e colchão; Comissão sobre o lucro líquido em forma percentual.

Ter um ambiente agradável, ter respeito entre os funcionários e a empresa, ter carga horária justa.

Respeito à jornada de trabalho, moveis ergonômicos, temperatura adequada e promoção de atividades para integração dos colaboradores.

40B Trabalhar com tranqüilidade, tendo respeito e reconhecimento.

$41 \mathrm{~B}$

42B

$43 B$

$44 \mathrm{C}$

Carga de trabalho justa, respeito à dignidade da pessoa humana, ambiência saudável e salários justos (dignos).

Trabalho com satisfação e prazer; Ser reconhecido no ambiente de trabalho; Remuneração adequada.

Bom clima organizacional com respeito mútuo.

É trabalhar com baixos níveis de stress, com possibilidade de pausas entre as tarefas e ter ao lado pessoas felizes com a motivação necessária.

$45 \mathrm{C}$

$46 C$

Salário Justo, ambiente adequado, valorização profissional, diminuição da pressão e do assédio moral.

É ter respeito, seriedade, compromisso, comprometimento sempre aliado a um ambiente saudável, sem cobranças excessivas, sabendo respeitar a potencialidade de cada um.

$47 \mathrm{C}$

É garantia de boa produção e de saúde física e mental para os funcionários; Satisfação no trabalho.

48C Respeito e lealdade entre os colegas. Bom clima organizacional

49C Bom ambiente de trabalho, sem pressão por metas.

50C Trabalhar em harmonia, com desenvolvimento pessoal e buscando a integração da equipe.

51C É sentir-se bem no que faz, ter um local de trabalho agradável, onde possa confiar nos colegas e tempo suficiente para cumprir sua 


\title{
Participante Pergunta: Para você o que é Qualidade de Vida no Trabalho?
}

\author{
agenda
}

$52 \mathrm{C}$

Ambiente saudável, responsabilidades compatíveis e Metas de produção palpável.

$53 C$

É a empresa te dar todas as condições necessárias, sem pressões absurdas, para que você tenha tranqüilidade para desempenhar suas atividades de maneira tranqüila

$54 \mathrm{C}$

Situação de conforto mínimo capaz de criar condições satisfatórias aos interesses do empregado e do empregador

É ter condições adequadas de trabalho com ambiente favorável para

55C O desenvolvimento e crescimento profissional. É possibilitar ao funcionário bem-estar, satisfação e saúde no trabalho

56C Condição adequada de realização dos trabalhos propostos, aliado à práticas físicas de relaxamento e bom relacionamento interpessoal.

Uma série de fatores que contribuem para que o trabalho seja bem

57C feito, gerando satisfação para ambas as partes (empregador e funcionário)

Trabalhar sem pressão dos superiores; Sem pressão no

58C cumprimento de metas; Mobiliário adequado; lluminação adequada e no meu caso que sou caixa, cumprimento da lei da fila

59C É trabalhar num ambiente agradável, com bom relacionamento e salário digno

Penso que para ter qualidade de vida no trabalho é fundamental um

60C bom ambiente de trabalho, onde se tenha uma remuneração compatível com a atividade desenvolvida e, no caso do Banco, metas factíveis com a realidade

São medidas tomadas pela organização e seus colaboradores que 61C tornam o ambiente laboral o mais saudável possível, trazendo ao funcionário um estado físico e psicológico mais adequado para trabalhar.

62C Relação entre todos os funcionários com igualdade, tanto nas tarefas como na renda.

63C Ter bem estar, equilíbrio físico, psíquico e social no ambiente de trabalho.

Sensação de bem-estar contínuo no ambiente de trabalho e 64C sentimento de realização profissional ainda que diante das situações de maior adversidade

65C Trabalhar com dignidade e ter tranqüilidade 


\section{Participante Pergunta: Para você o que é Qualidade de Vida no Trabalho?}

$66 \mathrm{C}$

Trabalhar com os recursos disponíveis necessários para a execução das tarefas; Bom clima organizacional.

$67 \mathrm{C}$

Trabalhar em ambiente adequado. Atuar em áreas condizentes ao seu perfil. Receber apoio nos desafios apresentados. Valorização pessoal.

$68 \mathrm{C}$

Um conjunto de situações como: trabalhar num clima de respeito, perto de seus familiares.

69C Trabalhar com saúde, local confortável, sem estresse.

70D Trabalhar com nível mínimo de Stress. Sempre motivado

71D

$72 \mathrm{D}$

É um estado de bem estar físico, mental e social e não só a ausência de doenças oriundas do estresse ocupacional

É um conjunto de ações que envolvem diagnósticos e implantação de melhorias e inovações gerenciais, tecnológicas e estruturais na empresa

Poder desenvolver as atividades normais dentro de um prazo

73D julgado necessário; Bom relacionamento com gerentes e colegas; Reconhecimento do Trabalho

É ter tempo para fazer as tarefas, é sair do serviço com uma sensação de dever cumprido e não com a sensação de não adianta nada

$75 \mathrm{D}$

É trabalhar com condições adequadas, isto é, mobiliário confortável, temperatura agradável, bom ambiente, tempo para descanso/relaxamento

Uma série de fatores que potencializam a QVT, dentre as quais

76D podemos citar: ambiente adequado, metas abusivas, assedio moral, carga excessiva de trabalho

77D Condições para que você possa desenvolver suas atividades com tranqüilidade, prazer e dedicação

É poder realizar minhas tarefas sem comprometer minha saúde 78D física e mental, e isso muitas vezes não é possível, segundo as condições de trabalho que temos hoje no Banco

$79 \mathrm{D}$

81D

Respeito à dignidade do funcionário; Bom relacionamento junto à equipe; Infra-estrutura e um ambiente saudável, limpo e agradável

Trabalhar somente durante o horário do seu contrato de trabalho; Ter bom relacionamento interno; Mobiliário funcionando; Salário Justo

82E É um conjunto de ações desenvolvidas pelas empresas, tendo em vista propiciar melhorias e condições de desenvolvimento do 
Participante Pergunta: Para você o que é Qualidade de Vida no Trabalho? empregado.

83E Boas condições para desenvolvimento das tarefas, clima agradável sem quantidade excessiva de tarefas.

84E Bem estar dos funcionários

Boas condições de trabalho, clima organizacional, com salários 85E justos, carga de trabalho adequada, bem estar físico e mental, instalações adequadas, bom relacionamento com os colegas.

$86 \mathrm{E}$

Momentos de relaxamento, bom clima organizacional, valorização dos funcionários, reconhecimento de competências.

$88 \mathrm{~F}$

Relações de emprego onde haja a justa paga e o respeito aos interesses da organização e colaborador

89F É ter satisfação laboral.

90F Ter condições para a execução dos trabalhos já seria um avanço. A sobrecarga e a falta de gestão competente dificultam ter bem estar.

93F Ter um bom ambiente de trabalho, contrapartida do empregador pelos esforços excessivos.

94F Ter ambiente favorável ao bom desempenho do trabalho. Recompensar o trabalho realizado de forma justa. 


\section{Apêndice E - Respostas à pergunta: Qual a sua opinião sobre o programa Qualidade de Vida no Trabalho do Banco do Brasil?}

\section{Participante Pergunta: Qual a sua opinião sobre o programa Qualidade de Vida no Trabalho do Banco do Brasil?}

$1 \mathrm{~A} \quad$ Cultura do "panis circus"

$2 \mathrm{~A}$

Boa iniciativa a fim de proporcionar melhores condições de trabalho para o funcionário.

$3 \mathrm{~A}$

Acho pouco abrangente e em quantidade de tarefas muito pouca.

$4 \mathrm{~A}$

Acho a idéia ótima, porém pouco eficaz.

$5 \mathrm{~A}$

Muito bom. Poucas empresas têm condições de oferecer o que o banco nos oferece.

$6 \mathrm{~A}$

Não tenho conhecimento sobre tal programa, se existe deveria ser mais divulgado para os funcionários.

Acredito que essa qualidade de vida fica comprometida quando o

7A ambiente da agência não esta bom. Neste caso especifico da agência Shopping Planaltina tem.

8A Meia Boca.

$10 \mathrm{~A} \quad$ Falta divulgação.

$11 \mathrm{~A}$ completo, que o banco tenha políticas que proporcionem também melhoria de qualidade de vida de seus colaboradores.

12A É bom, porem como o horário de entrada varia, nem todos podem participar.

Ainda fica muito a desejar, visto que após as 8 horas de trabalho,

13A vem à noite e o cansaço do dia a dia, não há animo para teus problemas pessoais.

14A Ainda está começando, precisa melhorias principalmente em relação a verbas para ser investidas na qualidade de vida dos empregados.

Muito bom, no meu entendimento o Banco tenta e faz atividades

15A para dar ao funci uma boa qualidade de vida. Sempre vai ter o que melhorar.

16A Não conheço.

17A È bom mais deixa a desejar no aspecto moral (alguns colegas) e no 
Participante Pergunta: Qual a sua opinião sobre o programa Qualidade de
Vida no Trabalho do Banco do Brasil? aspecto financeiro.

$18 \mathrm{~A}$

É um excelente programa, devem ser intensificadas as ações do programa.

19A

O programa é bom, porém não funciona na pratica devido às metas e poucos funcionários.

20B Já melhorou muito mas pode ser feito mais

21B

Pode ser melhor. Deixa muito a desejar, excesso de trabalho

22B Muito fraco

23B Regular

25B Bom

26B

Os programas desenvolvidos pelo Banco tiveram ganhos significativos, dando oportunidades para todos que desejem participar

27B Deixa muito a desejar. É bom na teoria e fraco na prática

28B Não funciona

29B Extremamente fraco e sem sucesso. Um circo totalmente sem graça

31B Esta boa, porém tem condições de melhorar

32B Não conheço profundamente

33B É uma sementinha que fora plantada e esta começando a germinar, ainda tem muito para fazer

34B Deixa muito a desejar.

36B trabalho/oferecimento de boas atividades da ECO para os funcionários

38B

O Banco investe em QVT mais ainda tem muito que melhorar, principalmente em relação à satisfação do funcionário

Não é muito eficiente, visto que as ECOAS não tem supervisão direta.

40B Poderia ser melhor

41B Tenho pouco conhecimento sobre o programa

42B Não Conheço 
Participante Pergunta: Qual a sua opinião sobre o programa Qualidade de
Vida no Trabalho do Banco do Brasil?

Creio que possui etapas importantes atingidas. Claro, há condições de melhorias como uma melhor utilização de horas para treinamento (cursos) auto-instrucionais. Geralmente os cursos são feitos em casa, diferente dos normativos.

44C Desconheço o programa, não tenho como esboçar minha opinião

45C Qualquer iniciativa do tipo destinação de verba, cai por terra devido à pressão por metas e assédio moral

46C Acredito que poderia ser bem melhor tendo em vista que nem todo mundo é vendedor, o que torna a cobrança por metas alta.

47C Fraco

48C Poderia ser melhor. Com mais diálogo e mais transparência.

49C Na teoria é muito bom, porém é impossível de se colocar em prática

50C Precisa dedicar melhores ações no sentido de desafogar a quantidade absurda de competências para os comissionados

$\mathrm{Na}$ teoria esta tudo muito bom. Na prática, deixa muito a desejar. Os

51C funci de agência têm que ser mais respeitados pelos seus superiores e não só obedecer sem poder questionar.

52C Desconheço.

53C Não tem programa definido no Banco do Brasil.

54C Falta efetividade

55C Tendo em vista a limitação de recurso, não atende com plenitude as necessidades dos funcionários

O Banco oferece verba para despesas em ações de QVT. Caba a 56C cada agência optar por uma ou mais ações, entre as mais usadas estão: massagens expressas, dança de salão e ginásticas laborais

57C É limitado e não conta com a participação de todos

58C Fraca sem comentários

59C Desconheço

60C Qualidade de vida no Banco do Brasil? Nunca vi.

61C Por ser novato no Banco, ainda não conheço adequadamente.

62C É falho, não chega às agências.

63C Razoável, mas deve ser aprimorado. 


\section{Participante Pergunta: Qual a sua opinião sobre o programa Qualidade de Vida no Trabalho do Banco do Brasil?}

$64 \mathrm{C}$

Insuficiente, inócuo, não ajustado à realidade das dependências. Quase mentiroso

65C Acho péssimo, ainda não conheci este programa.

66C Entendo que ainda são ações tímidas que pouco contribuem com a melhoria. Há muito ainda a avançar

67C Perfeito na teoria, não funciona na prática.

68C Como os outros programas: Excelente na teoria e na prática uma porcaria

$69 \mathrm{C}$

$70 \mathrm{D}$

Não tenho informações sobre o programa de qualidade de vida no trabalho

Não esta surtindo os efeitos desejados pela empresa

71D

Eu não conheço muito sobre o programa devido à falta de tempo para me informar. O trabalho que eu conheço é o trabalho da equipe ECOA que em minha opinião presta um bom trabalho

72D Desconheço tal programa

$73 \mathrm{D}$

Ótimo, principalmente no investimento que a empresa faz em seus funcionários

Muito vago, não há um programa definido. Só tem o dinheiro para a agência/ECOA decidir o que fazer

$75 \mathrm{D}$

Satisfatório. Além dos programas próprios das agências, deveriam ter convênios regionais e nacionais contemplando a QVT

76D Deixa muito a desejar

77D Sem consistência e comprometimento

78D O programa em si é bom, mas aplicabilidade não esta sendo totalmente efetivada

79D Tem oferecido melhorias, contudo deve ter um enfoque maior e direto na realidade dos funcionários das agências

81D Não funciona. O programa é lembrando algumas vezes durante o ano, não tem continuidade de processo

82E Como tenho pouco tempo de empresa, ainda não tenho conhecimento sobre o programa.

83E Fraco

84E Razoável. 
Participante Pergunta: Qual a sua opinião sobre o programa Qualidade de
Vida no Trabalho do Banco do Brasil? É interessante, mas considerando a complexidade das atividades 85E desenvolvidas acredito que deveria ter maiores incentivos para esportes e práticas de atividades físicas.

86E Não existe

88F A meu ver ainda é muito incipiente

89F À aprimorar.

90F Serve apenas para apresentar dados para a agenda 21. Na prática acontece apenas em algumas agências.

92F Desconheço

93F Não compensa nem de longe o estresse de trabalho.

No que se refere a minha agência a qualidade é zero, pois não há ambiente, a agência em si (fisicamente) propícia ao bom desempenho, nem funcionários suficientes, o que torna 0 bom desempenho impossível. 


\section{Apêndice F - Respostas à pergunta: Que sugestão você faria para contribuir com a qualidade de vida no seu ambiente de trabalho?}

\section{Participante Pergunta: Que sugestão você faria para contribuir com a qualidade de vida no seu ambiente de trabalho?}

$1 \mathrm{~A}$

$3 \mathrm{~A}$

Ambiência, ações efetivas para melhoria da vida do funcionário

Melhores instalações principalmente contra ruídos e temperatura, clara e manifesta intenção dos superiores em relação às ações dos subordinados.

Devemos nos ajudar, procurar fazer nossa parte para que o 4A trabalho seja realizado sem sobrecarregar ninguém. Manter o bom clima organizacional ao se esforçar para manter boas relações no trabalho.

A melhoria das instalações físicas, além de melhores horários de 6A trabalho possibilitando uma maior flexibilidade para os funcionários para atividade de aprimoramento.

A capacitação e o treinamento adequado para todos os funcis e

7A colaboradores, onde todos estão cientes de seu papel na organização.

8A Toda agencia ter um orientador.

10A Implantar confraternizações.

Alteração no tratamento das lideranças do banco em relação aos

$11 \mathrm{~A}$ subordinados.Fiscalização pelo banco, das cobranças excessivas dos gestores sobre a equipe.

Quem sabe a implantação das 6 horas de trabalhos para comissionados.

Maior convívio entre membros da equipe, principalmente em eventos fora do ambiente de trabalho.

15A Destinar um tempo para os funci alargar e descontrair.

17A Melhorias nas necessidades (elevador), substituição de equipamentos antigos.

Especificamente na minha agencia o ambiente físico em si é um dos fatores que mais comprometem o rendimento dos funcionários, por isso minha sugestão seria investir no ambiente físico.

19A Conjugar as metas com o programa QVT.

20B Tentar criar um clima melhor entre os colegas 
Participante Pergunta: Que sugestão você faria para contribuir com a qualidade de vida no seu ambiente de trabalho?

Melhorar os salários, carga de serviço menor e contratar mais funcionários

Realizar reuniões comemorativas extra-banco com os colegas de trabalho

Diminuição da quantidade de serviço e menor pressão pelo cumprimento de Metas

O envolvimento da ECOA para conscientizar todos os funcionários da unidade a participarem dos programas

27B

Ouvir os funcionários sobre as dificuldades encontradas entre eles

28B Criação de normas de conduta para inibir o assédio moral

29B

Reunião com equipe toda semana onde são expostos os erros e acertos de todos e que o gestor/gerente da equipe tentasse minimizá-los

30B Aliar a prática de exercícios com os deveres do trabalho

33B Maior interação entre os funcionários

$36 \mathrm{~B}$

Melhorar o mobiliário tornando-o mais funcional, esse seria um grande passo dentro do BB, evitando muitos dos casos de DORT e LER.

$37 \mathrm{~B}$

Revezamento de funcionários no atendimento externo, o autoatendimento.Hoje os funcionários têm que ficar as quase 4 horas em pé.

38B Mais respeito da instituição com relação aos funcionários

39B

40B Contratação de mais funcionários

Jornada de trabalho de 6 horas, tempo para treinamentos e

42B estudos e fazer atividades que não venham a ser rotineiras (serviços repetitivos). Melhores Salários

Melhor climatização dos ambientes; Melhoria nos processos de 43B treinamentos auto-instrucionais; Melhoria no clima/relação entre os funcionários (geralmente de níveis hierárquicos diferentes).

Mais funcionários, mais cursos de aperfeiçoamento, melhor análise das reais necessidades de cursos, melhores salários, menor "engessamento" do plano de carreira, seleções internas 
Participante $\begin{aligned} & \text { Pergunta: Que sugestão você faria para contribuir com a } \\ & \text { qualidade de vida no seu ambiente de trabalho? }\end{aligned}$ com avaliação e não apenas dependente de indicação

45C Maior liberdade para trabalhar e menos assédio moral

46C Aproveitar melhor as habilidades de cada um nas áreas diversas dentro do Banco

47C Ginástica laboral; móveis adequados; Temperatura adequada.

48C Mais oportunidades para os funcionários das agências. Preocupação da empresa com o objetivo das pessoas.

Diminuição das metas, diminuição da carga horária, aumento $49 \mathrm{C}$ salarial, menos burocracia nos processos, ambientes específicos para vendas de determinados produtos, treinamento de qualidade.

$50 \mathrm{C}$

Mais integração da equipe, melhor distribuição das tarefas, maior quantidade de funcionários, realização de cursos e fazap.

Dentro do possível o funcionária poderia escolher seu horário de trabalho, quer dizer uma diferença de 20 a 30 minutos desde que não seja no horário ao público não faz diferença para Banco. E sermos reconhecido como patrimônio do Banco.

52C Maior distribuição de atribuição de tarefas

53C Melhores salários

54C As ações devem compor as rotinas diárias e não limitar-se a procedimentos isolados

$55 \mathrm{C}$

Mais organização no ambiente físico, mais tempo para aprimoramento pessoal/profissional.

57C Primeiramente, melhoraria a ergonomia das mesas e cadeiras e trocaria as máquinas por mais novas

Trabalhar sem pressão dos superiores; Sem pressão no 58C cumprimento de metas; Mobiliário adequado; lluminação adequada e no meu caso que sou caixa, cumprimento da lei da fila

$59 \mathrm{C}$ Oferecer melhores condições para atendimento aos clientes, evitando demora e consequentemente reclamações

60C Menos metas abusivas, incompatíveis com a realidade de trabalho, mais valorização dos funcionários

61C Contratar profissional que ensina, em 2 ou 3 encontros, a 


\section{Participante Pergunta: Que sugestão você faria para contribuir com a qualidade de vida no seu ambiente de trabalho?}

ginástica laboral, para minimizar os danos da digitação.

62C Integração com funcionários de todas as esferas do Banco

63C Aumento no número de funcionários para poder redistribuir as tarefas

Desenvolvimento de ações para melhoria do clima, 64C intensificação das relações interpessoais entre a equipe, redução de sobrecargas pontuais, valorização profissional com reconhecimento a colegas e melhor gestão.

65C Ter mais ética por parte dos superiores

66C Melhor interação entre colegas da agência; Uma atuação mais forte da ECOA.

67C particularidades, que fossem analisadas e atendidas dentro do possível.

Que os funcis vinculados às agências pudessem participar destes grupos de trabalho. Até um programa como este é 68C decidido como sempre, de cima para baixou. Diretoria e outros setores hierárquicos não conhecem a realidade das pressões que sofremos

69C Momentos de descontração com a equipe. Happy hous.

70D Divisão mais justa das atividades; Redução da jornada de trabalho para 6 horas

Necessitamos de diversidade de práticas anti-estresse, dos 71D gestores criarem melhores condições para motivar os funcionários na realização de suas tarefas. Incentivar os funcionários praticar ginástica laboral antes do início do trabalho

Funcionamento adequado de equipamentos essenciais como: impressora, xérox, computador.

73D Melhorar um pouco o ambiente físico

74D Equipamentos melhores, uma integração maior de equipe

75D "zen" para descanso e relaxamento dos funcionários, visto que a maioria não mora no município

Mais funcionários nas agências, metas compatíveis e melhor reconhecimento do funcionário como ser humano 
Participante Pergunta: Que sugestão você faria para contribuir com a qualidade de vida no seu ambiente de trabalho?

77D Medidas que favoreçam o comprometimento do corpo funcional

78D funcionário, estresse é o maior problema que enfrentamos hoje. Acho que atividades relaxantes seriam muito bem aproveitadas em nosso dia-a-dia

79D Qualidade dos equipamentos, ambiência e organização pessoal dos funcionários

81D Que as atividades fossem no horário de trabalho e fossem constante

Como o trabalho ocupa a maior parte do tempo de nossas vidas, 82E procuraria me integrar mais com os meus colegas e proporia ações que diminuíssem o estresse habitual de uma agência bancária.

83E Maior quantidade de funcionários

84E Mais pessoal, sobretudo no varejo.

85E Estimular atividades e esportes em grupo contribuindo com o bem estar físico e mental.

86E Cumprir a CLT

88F Diminuição da carga de trabalho dos colaborares a níveis normais e a equalização entre agências.

89F Equipe completa + equipamentos adequados.

Pessoas em quantidade compatível com a demanda, 90F organização dos processos e metas compatíveis com os recursos. Em relação as metas, um planejamento adequado para se evitar mudanças constantes.

92F Mais Funcionários

93F Aumentar a quantidade de funcionários para dar melhores condições de trabalho e de atendimento para os clientes.

$94 \mathrm{~F}$

Ter quantidade de funcionários suficiente para atender o público da agência e espaço para tal. 


\section{ANEXOS}

\section{Anexo A - Instrumento de Coleta de Dados - Parte III}

\section{Pesquisa de Qualidade de Vida no Trabalho}

Este instrumento pretende avaliar se a sua empresa está preocupada com a qualidade de vida dos seus funcionários. Para tal, você deve avaliar cada uma das 31 afirmativas abaixo, indicadoras de qualidade de vida no trabalho, marcando com um $\underline{X}$ conforme os códigos seguintes:

\begin{tabular}{|ccccc|}
\hline Discordo & Concordo pouco & $\begin{array}{c}\text { Concordo } \\
\text { razoavelmente }\end{array}$ & Concordo muito & $\begin{array}{c}\text { Concordo } \\
\text { totalmente }\end{array}$ \\
0 & 1 & 2 & 3 & 4 \\
\hline
\end{tabular}

A minha organização:

1. Valoriza o trabalho dos funcionários

2. Recompensa a competência no trabalho

3. Dá liberdade para o funcionário executar o trabalho com seu estilo pessoal

4. Fornece a infra-estrutura material necessária para a execução do trabalho

5. Apóia o desenvolvimento pessoal

6. Investe para que o funcionário não mude de empresa

7. Fornece um bom suporte tecnológico para o desempenho do trabalho

8. Possibilita relações sociais agradáveis entre os funcionários

9. Estimula o bom relacionamento entre chefias e funcionários

10. Paga salários justos

11. Faz os funcionários se sentirem orgulhosos por trabalhar nela

12. Investe para que o ambiente físico de trabalho seja saudável

13. Assegura uma adequada jornada de trabalho

14. Oferece assistência médica

15. Oferece assistência odontológica

16. Exige respeito dos superiores para com seus colaboradores

17. Estimula o apoio dos superiores a seus colaboradores

18. Exige respeito dos colaboradores para com seus superiores

19. Reconhece os bons funcionários

20. Oferece bolsas de estudo para os funcionários

21. Oferece treinamento para os funcionários

22. Tem um sistema de promoção justo

23. Tem um sistema de comunicação claro

24. Reconhece os funcionários leais

25. Respeita os direitos trabalhistas

26. Respeita a liberdade de expressão

27. Respeita a privacidade

28. Promove eventos de recreação e lazer

29. Possibilita a realização profissional dos seus funcionários

30. Investe na segurança dos funcionários

31. Desenvolve programas de qualidade de vida no trabalho

Chegamos ao final deste momento, e para melhor qualificar esta pesquisa solicito que você responda a mais 2 itens, com a maior precisão possível:

1. Há quanto tempo você trabalha nesta organização?

2. Status: ( ) chefia ( ) subordinado

Muito obrigado pela sua valiosa colaboração! 
Anexo B - Fatores de QVT - Teoria de Walton (RIBEIRO, 2010)

\begin{tabular}{|c|c|}
\hline Fatores QVT & Questões \\
\hline $\begin{array}{l}\text { 1) Suporte à execução } \\
\text { do trabalho }\end{array}$ & $\begin{array}{l}\text { 1- Valoriza o trabalho dos funcionários; } \\
\text { 3- Dá liberdade para o funcionário executar o trabalho } \\
\text { com seu estilo pessoal; } \\
\text { 4- Fornece a infra-estrutura material necessária para a } \\
\text { execução do trabalho; } \\
\text { 7- Fornece um bom suporte tecnológico para o } \\
\text { desempenho do trabalho; } \\
\text { 12- Investe para que o ambiente físico de trabalho seja } \\
\text { saudável; } \\
\text { 13- Assegura uma adequada jornada de trabalho; } \\
\text { 21- Oferece treinamento para os funcionários; } \\
\text { 23- Tem um sistema de comunicação. }\end{array}$ \\
\hline 2) Relacionamento & $\begin{array}{l}\text { 8- Possibilita relações sociais agradáveis entre os } \\
\text { funcionários; } \\
\text { 9- Estimula o bom relacionamento entre chefias e } \\
\text { funcionários; } \\
\text { 16- Exige respeito dos superiores para com seus } \\
\text { colaboradores; } \\
\text { 17- Estimula o apoio dos superiores a seus colaboradores; } \\
\text { 18- Exige respeito dos colaboradores para com seus } \\
\text { superiores. }\end{array}$ \\
\hline $\begin{array}{l}\text { 3) Respeito } \\
\text { Profissional }\end{array}$ & $\begin{array}{l}\text { 5- Apóia o desenvolvimento pessoal; } \\
\text { 6- Investe para que o funcionário não mude de empresa; } \\
\text { 11- Faz os funcionários se sentirem orgulhosos por } \\
\quad \text { trabalhar nela; } \\
\text { 25- Respeita os direitos trabalhistas; } \\
\text { 26- Respeita a liberdade de expressão; } \\
\text { 27- Respeita a privacidade; } \\
\text { 29- Possibilita a realização profissional dos seus } \\
\quad \text { funcionários; } \\
\text { 30- Investe na segurança dos funcionários. }\end{array}$ \\
\hline $\begin{array}{l}\text { 4) Programas de } \\
\text { qualidade de vida }\end{array}$ & $\begin{array}{l}\text { 14- Oferece assistência médica; } \\
\text { 15- Oferece assistência odontológica; } \\
\text { 20- Oferece bolsas de estudo para os funcionários; } \\
\text { 28- Promove eventos de recreação e lazer; } \\
\text { 31- Desenvolve programas de qualidade de vida no } \\
\text { trabalho. }\end{array}$ \\
\hline 5) Recompensas & $\begin{array}{l}\text { 2- Recompensa a competência no trabalho; } \\
\text { 10- Paga salários justos; } \\
\text { 19- Reconhece os bons funcionários; } \\
\text { 22- Tem um sistema de promoção justo; } \\
\text { 24- Reconhece os funcionários leais. }\end{array}$ \\
\hline
\end{tabular}

